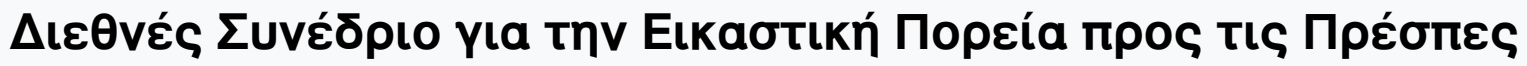

Tóp. 5 (2015)

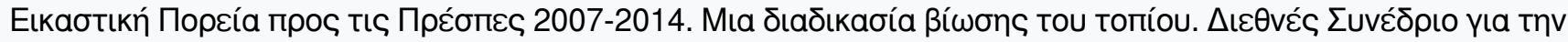

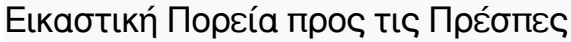

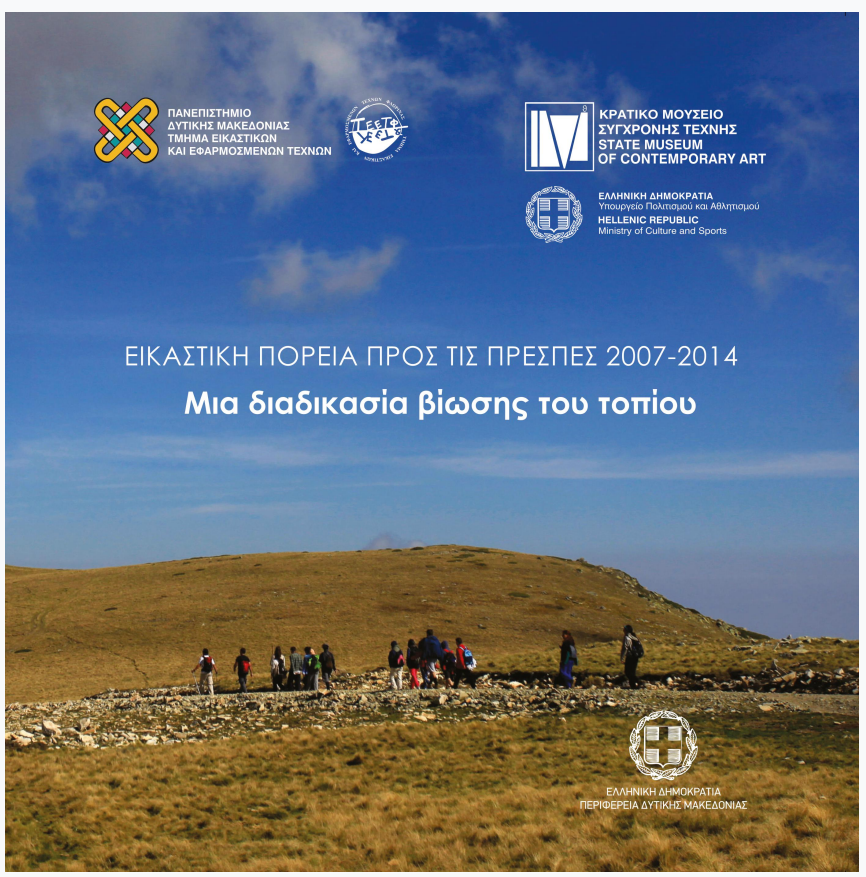

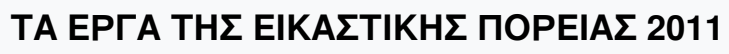

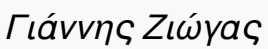

doi: $10.12681 /$ visualmarch.3080 


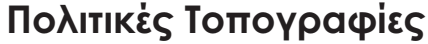

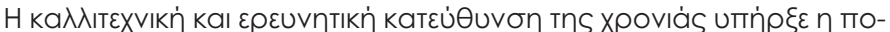

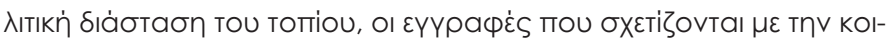

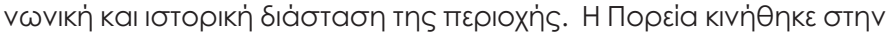

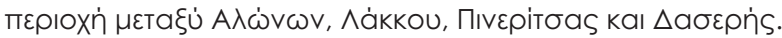

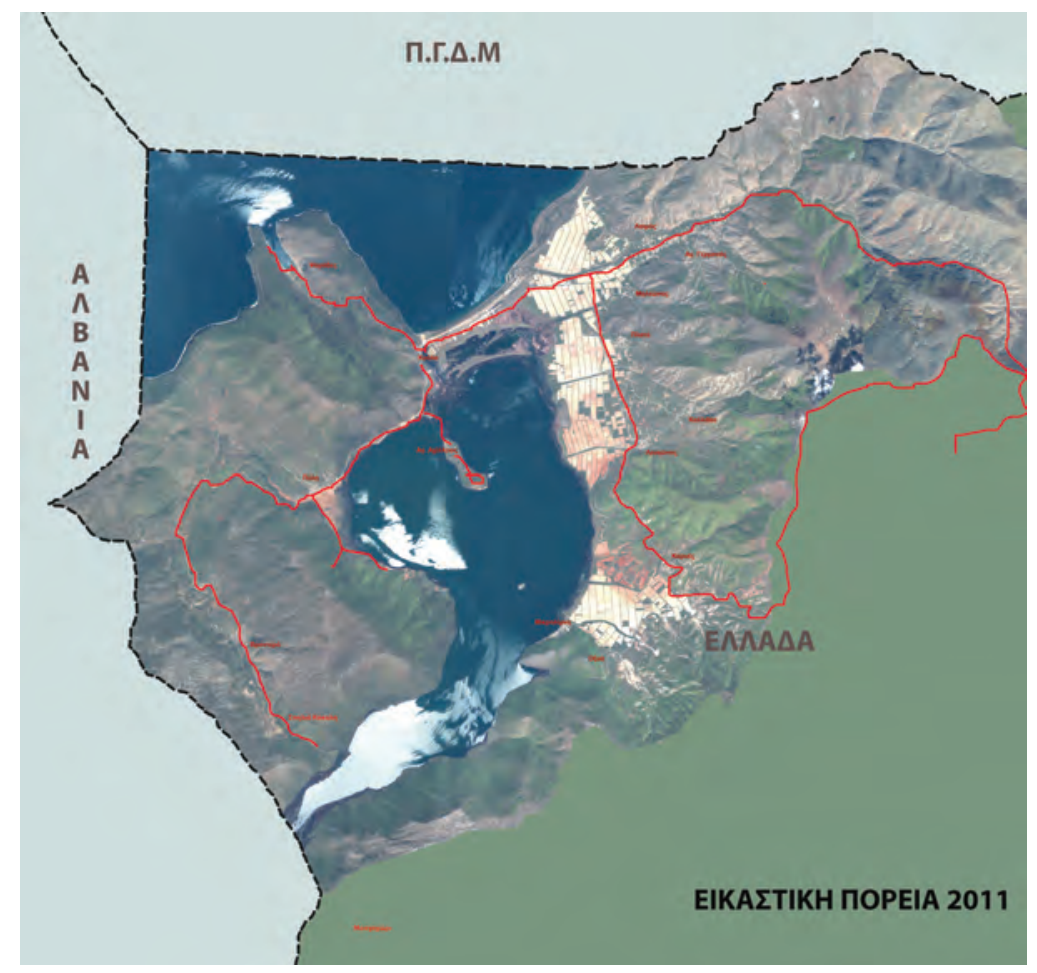




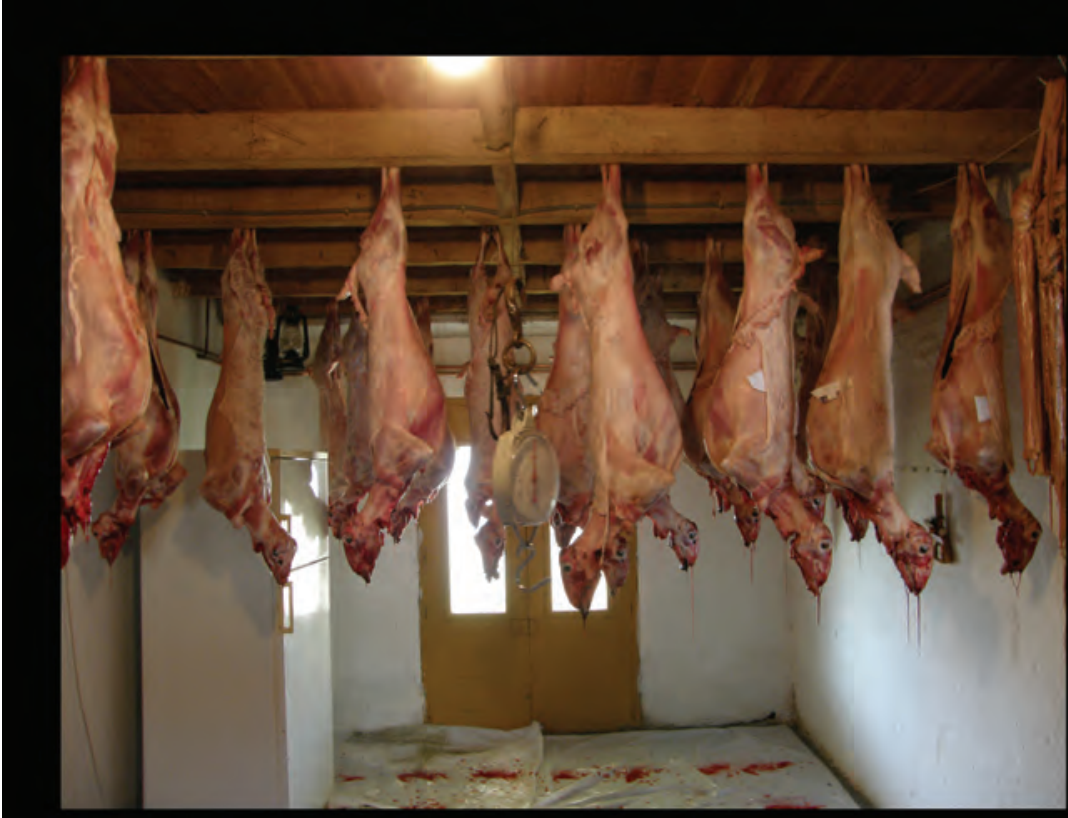

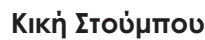

Mapia Пата入 $\varepsilon \xi i o u$

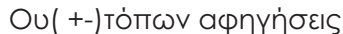

$\wedge$ ákKos

Проßı่̇s, 2011
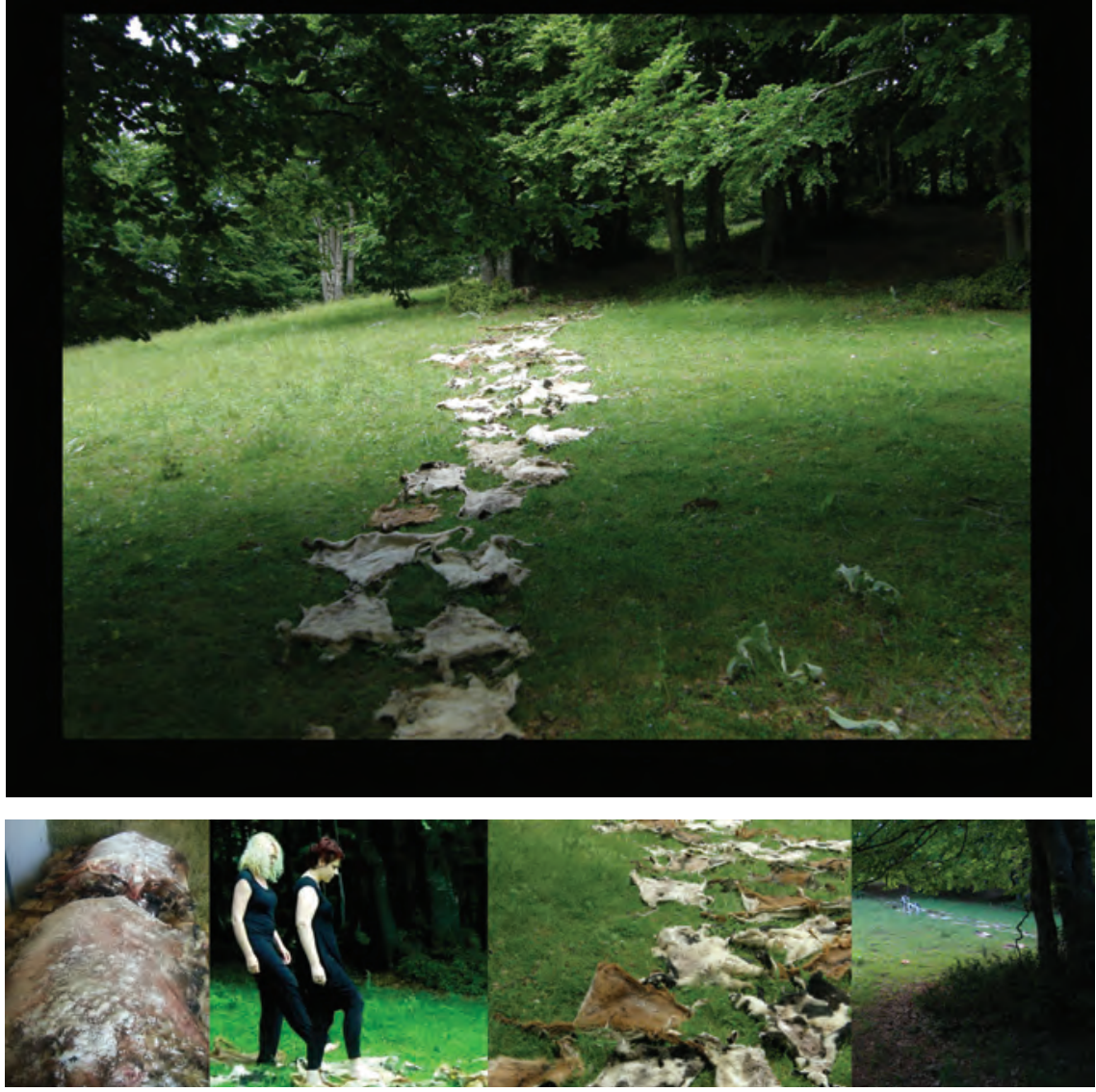


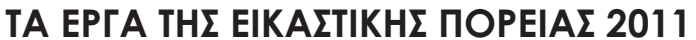

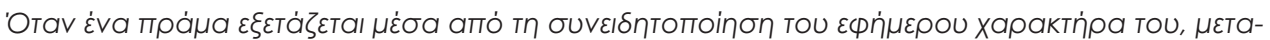

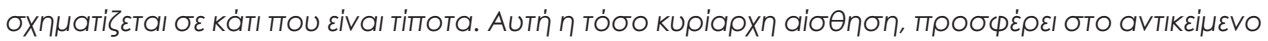

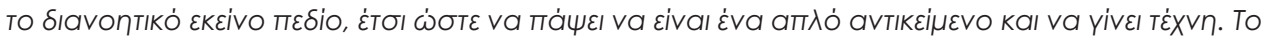

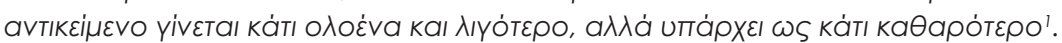

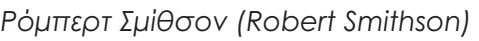

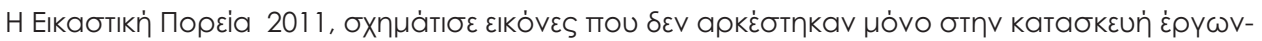

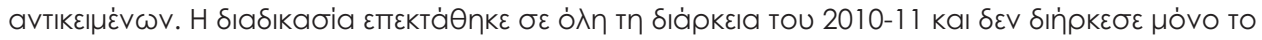

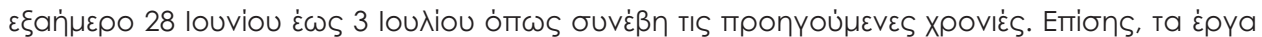

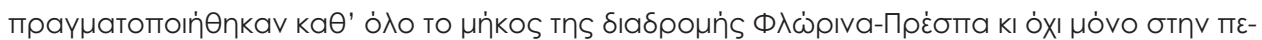

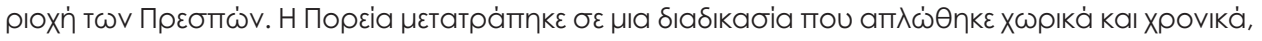

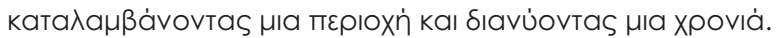

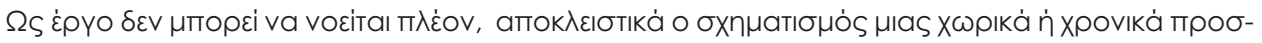

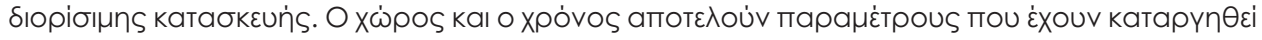

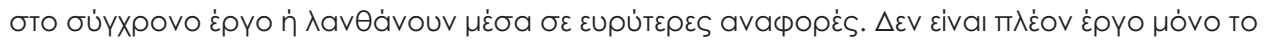

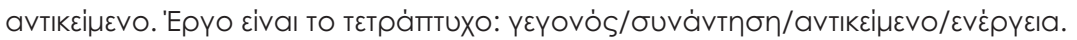

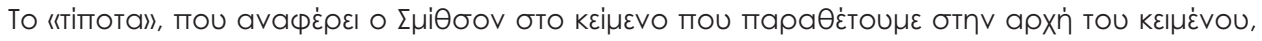

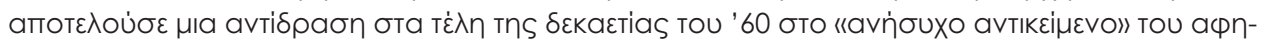

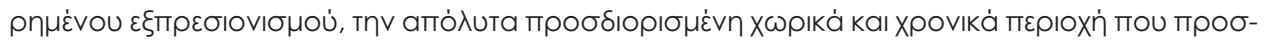

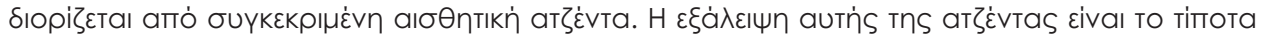

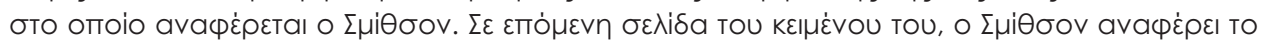

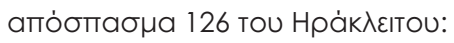

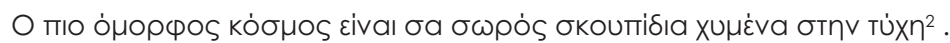

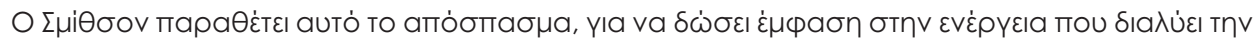

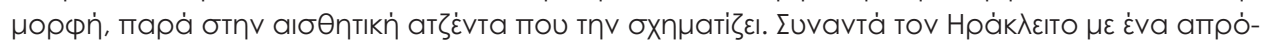

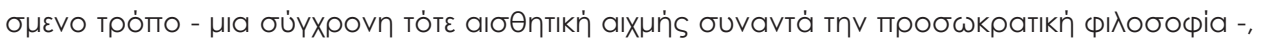

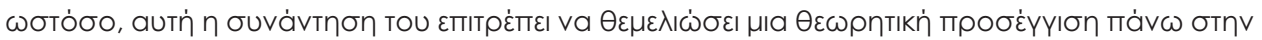

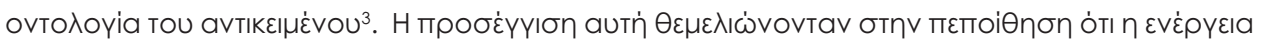

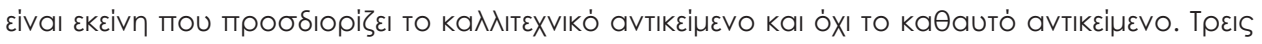

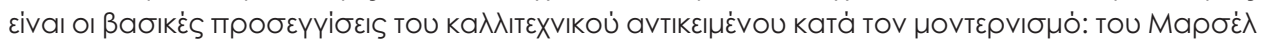

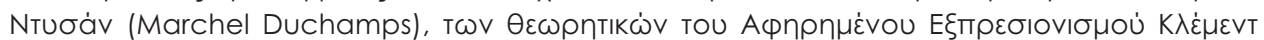

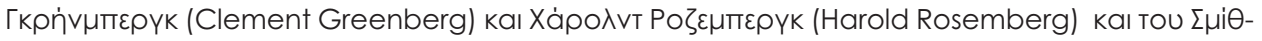

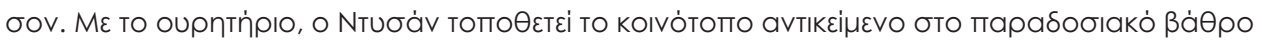

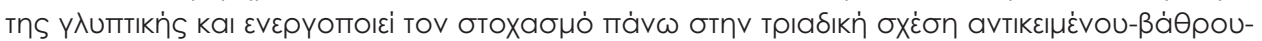

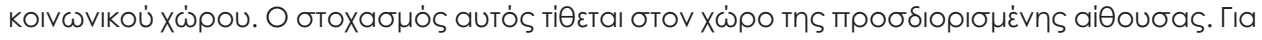

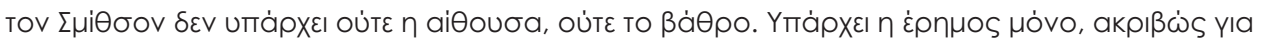

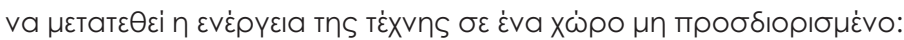

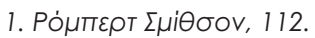

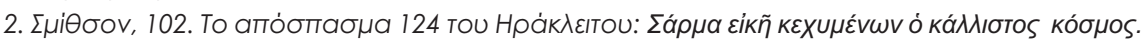

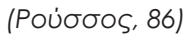

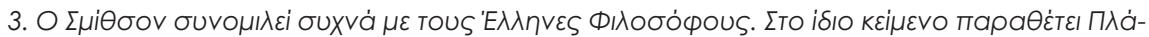

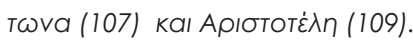




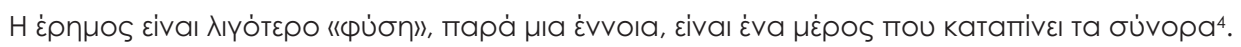

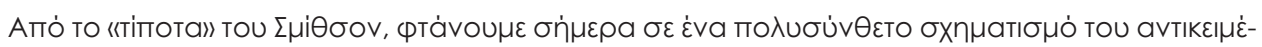

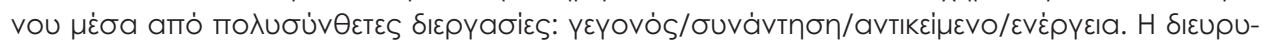

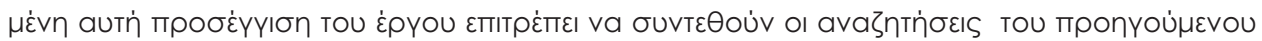

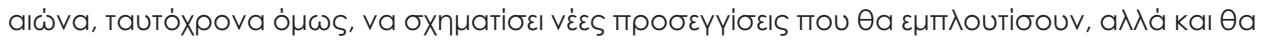

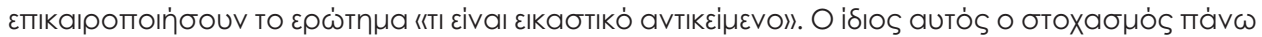

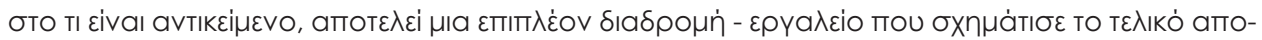

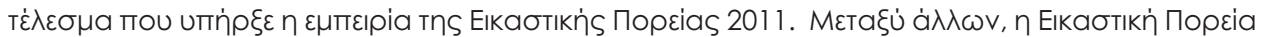

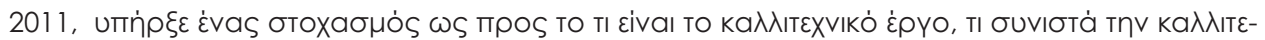

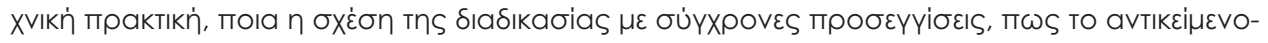

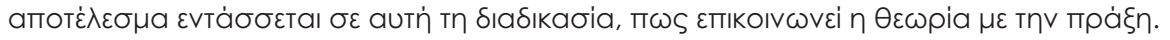

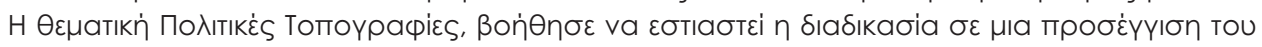

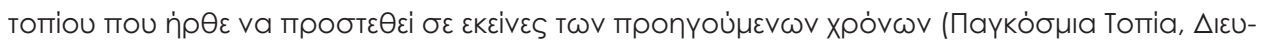

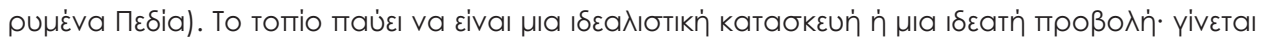

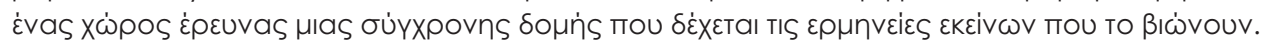

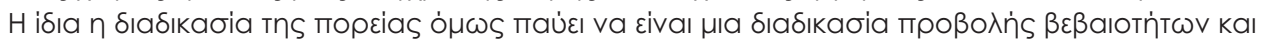

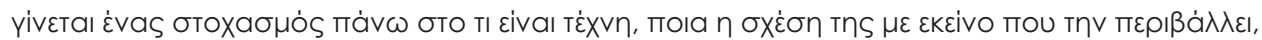

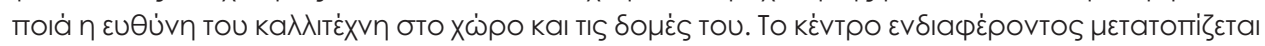

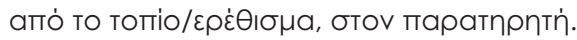

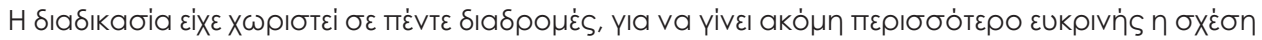

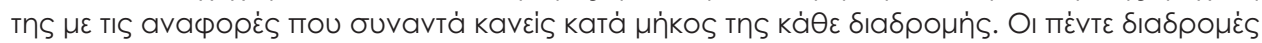

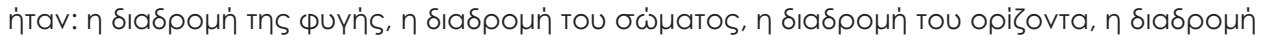

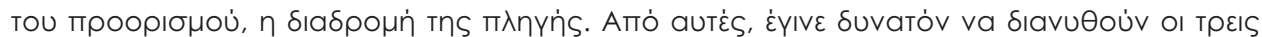

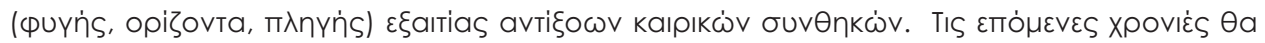

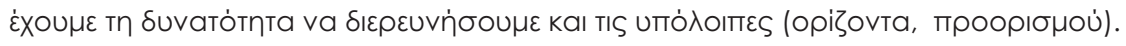

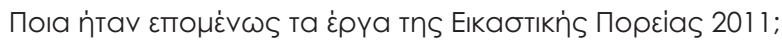

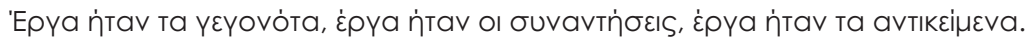

\section{Ta үعүovóta}

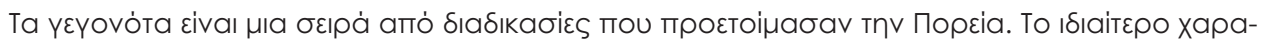

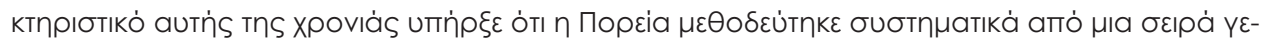

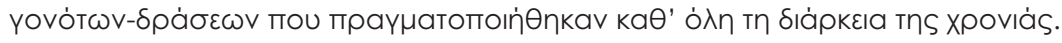

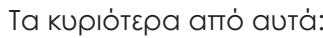

4. $\Sigma \mu i \theta \sigma o v, 106$. 


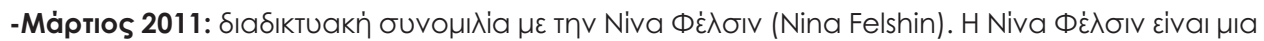

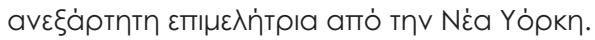

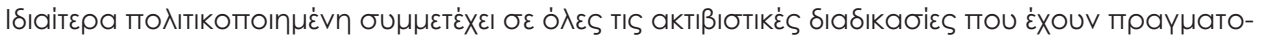

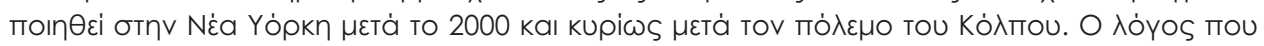

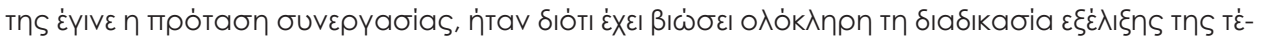

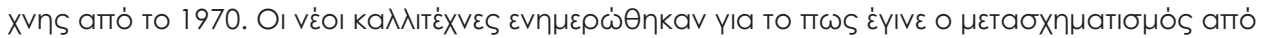

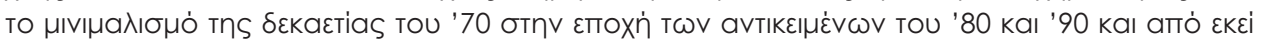

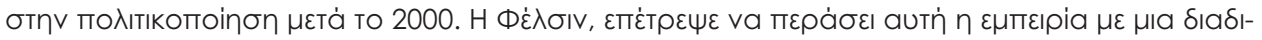

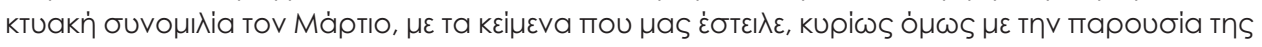

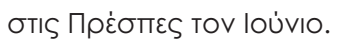

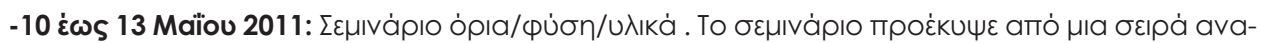

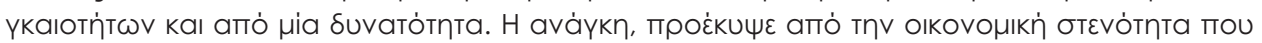

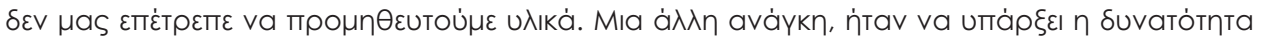

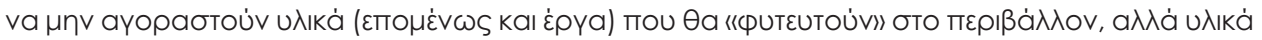

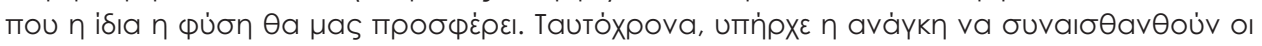

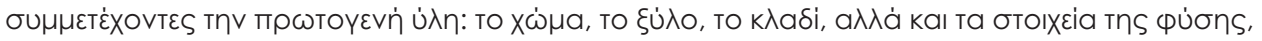

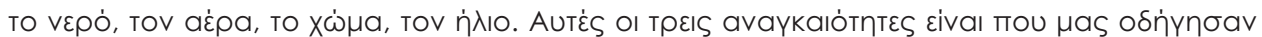

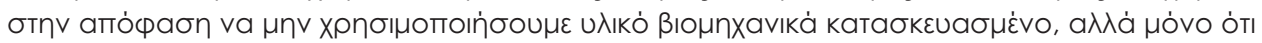

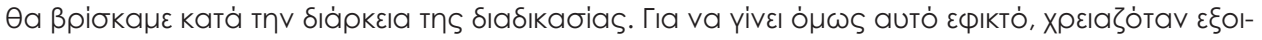

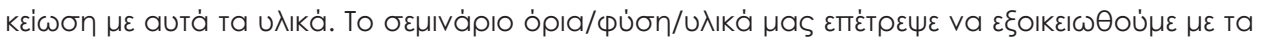

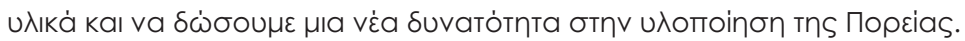

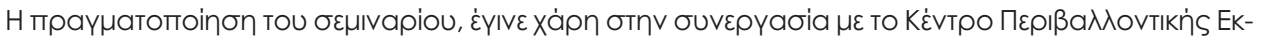

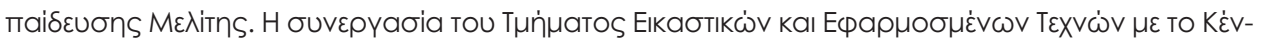

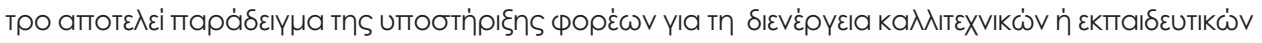

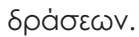

\section{-Máıs 2011: Jeep Trip to Prespes}

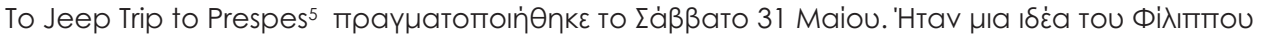

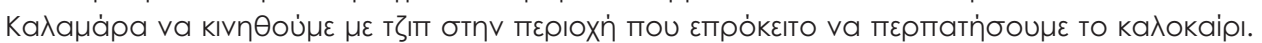

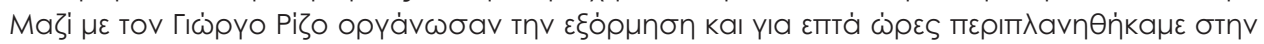

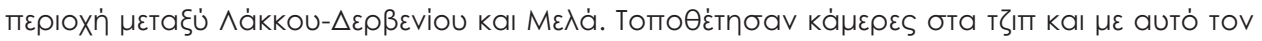

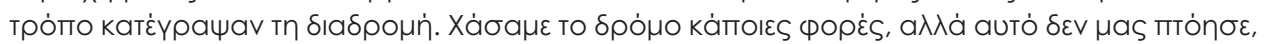

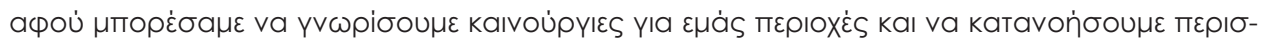
бо́твро то тотіо.

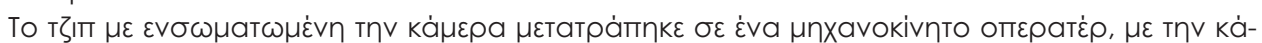

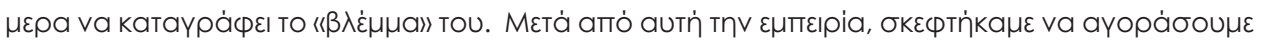

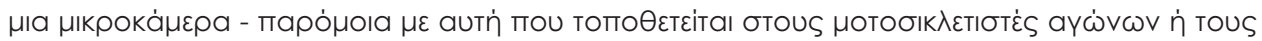

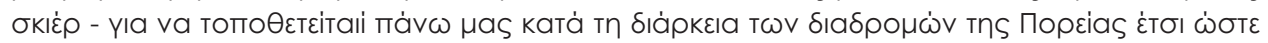

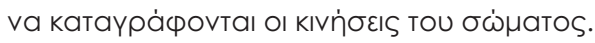

5. http://www.youtube.com/watch?v=-wToeUJbM48 


\section{-Máıs 2011-loúvıos 2011}

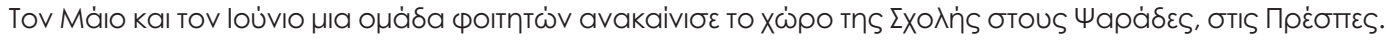

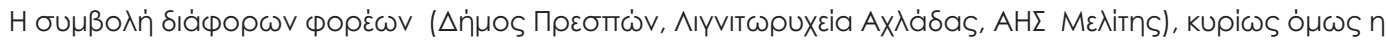

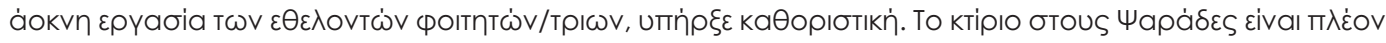

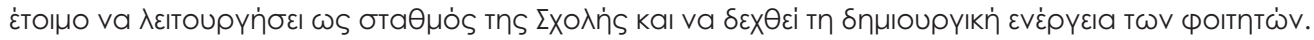

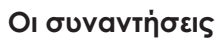

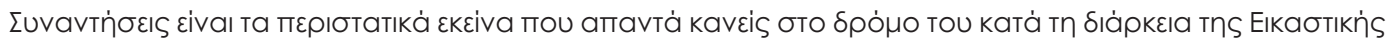

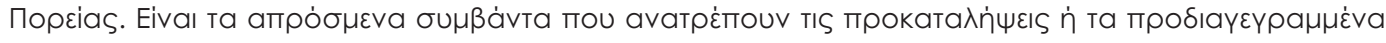

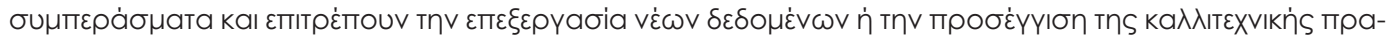

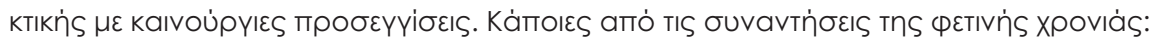

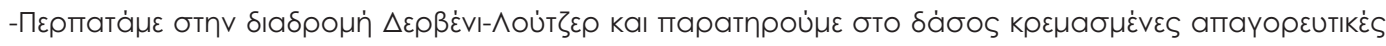

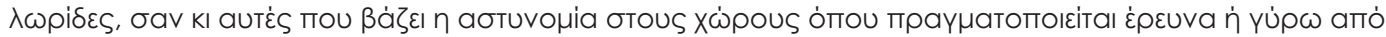

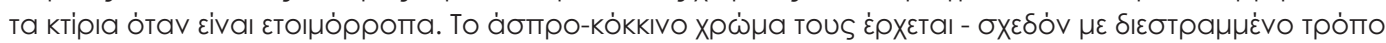

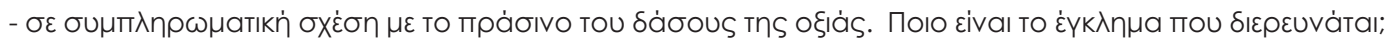

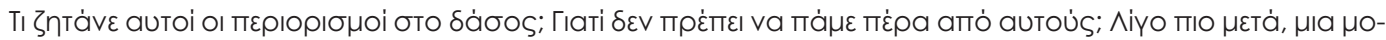

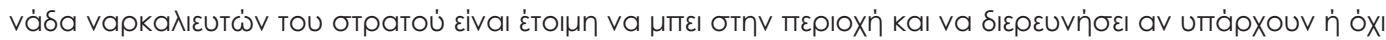

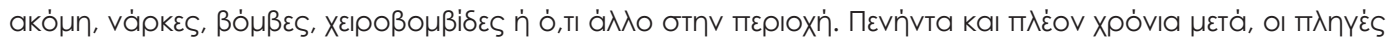

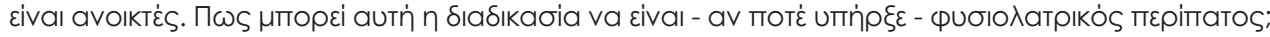

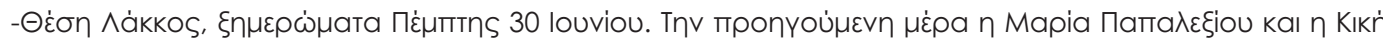

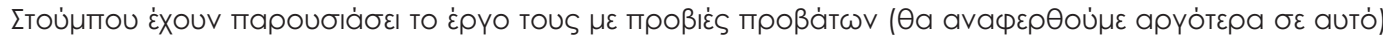

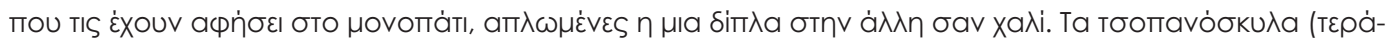

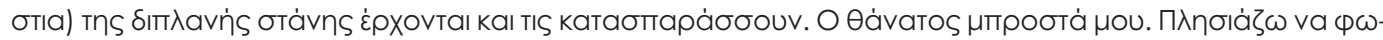

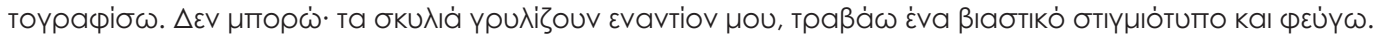

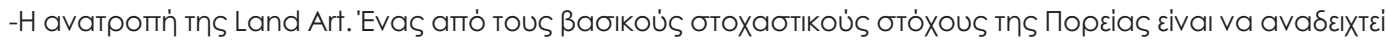

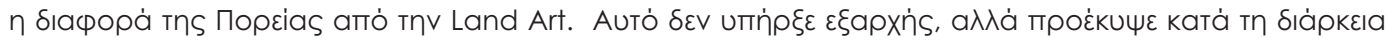

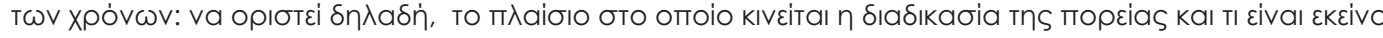

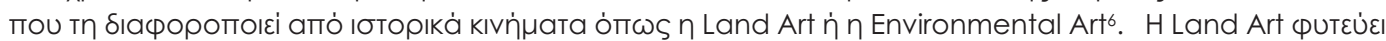

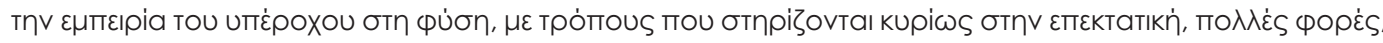

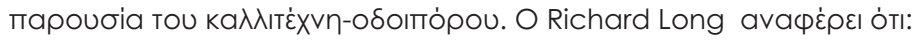

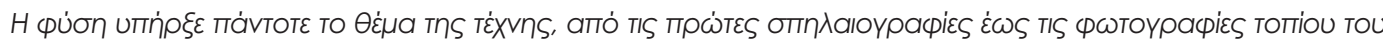

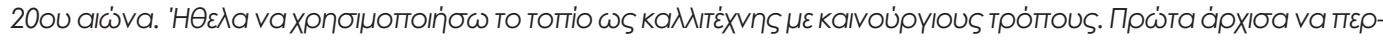

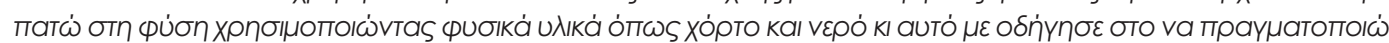

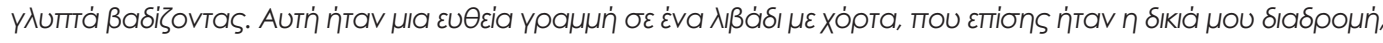

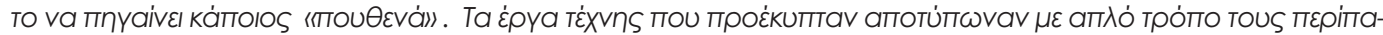

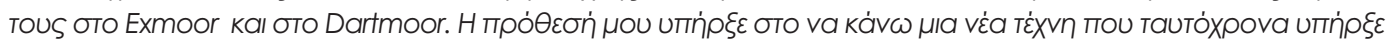

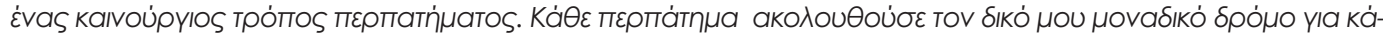

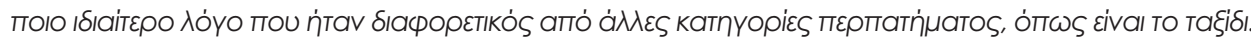

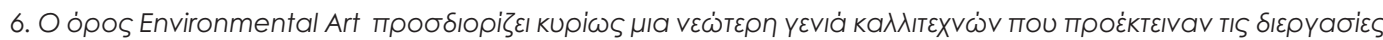

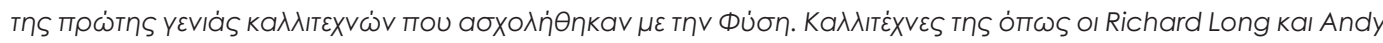

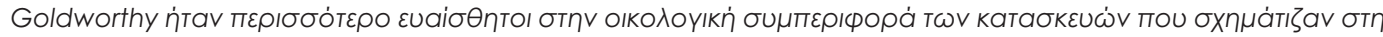

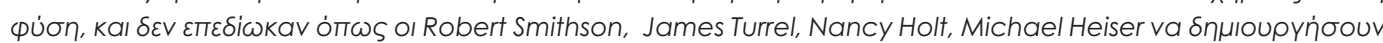

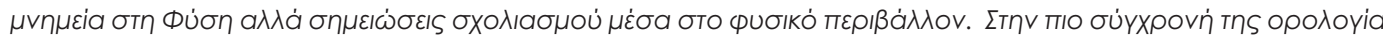

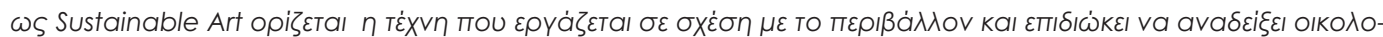

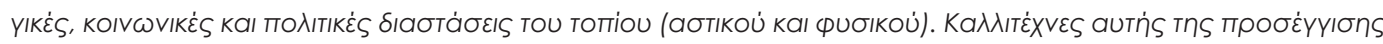

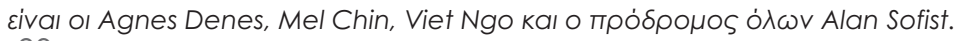
90. 


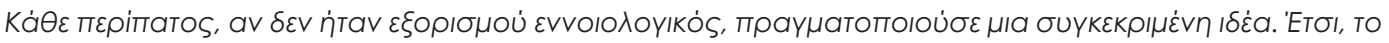

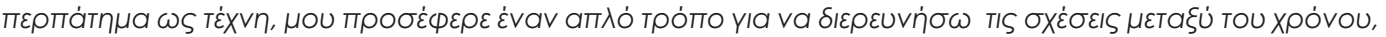

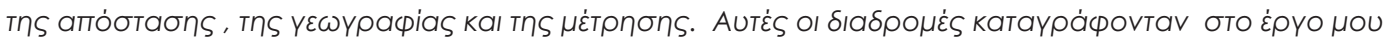

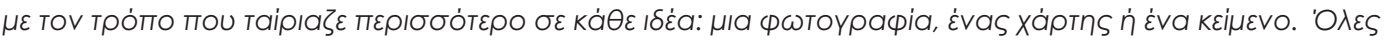

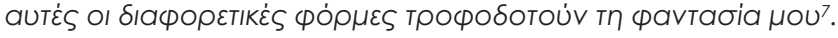

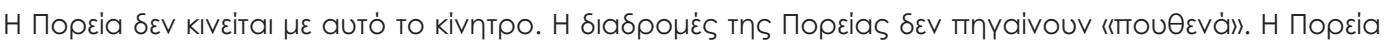

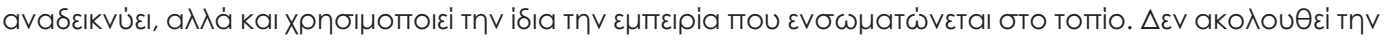

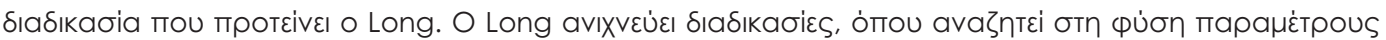

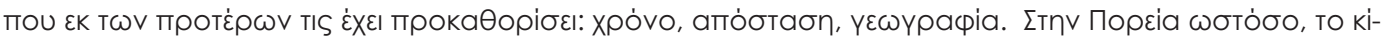

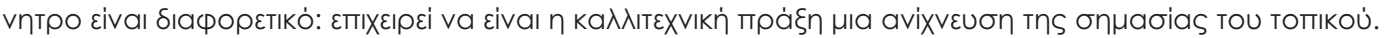

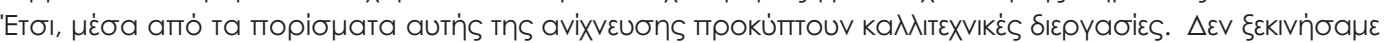

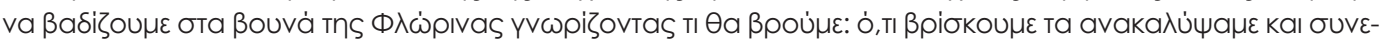

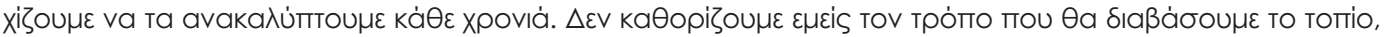

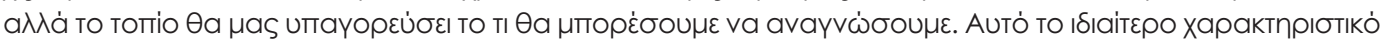

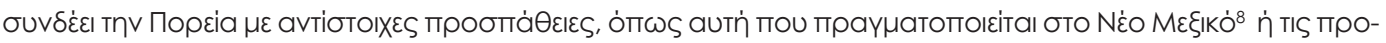

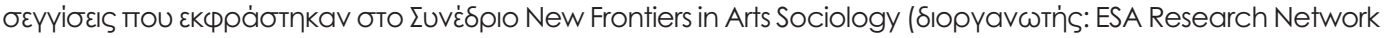

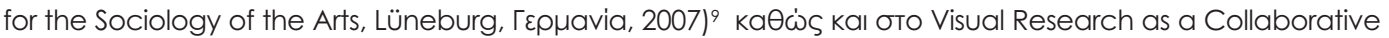

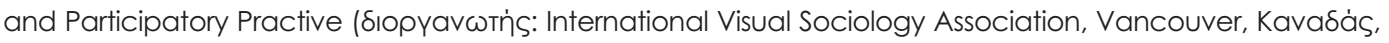
$2011)^{10}$.

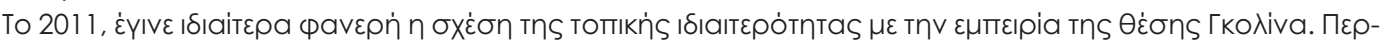

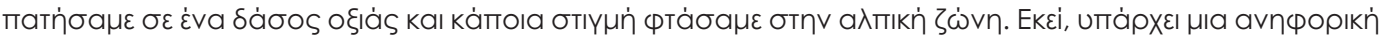

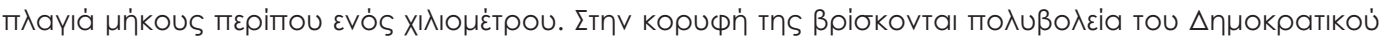

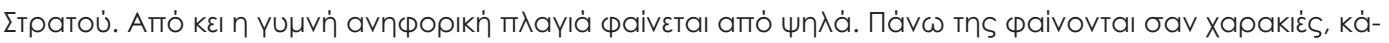

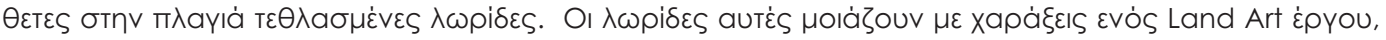

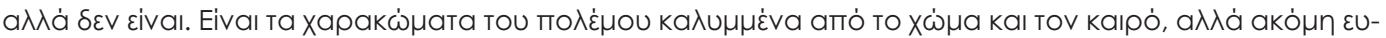

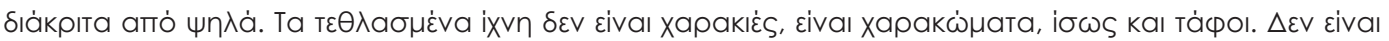

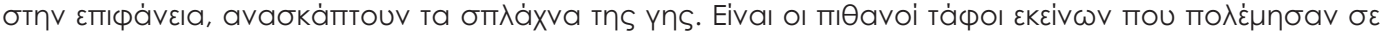

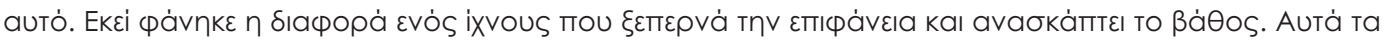

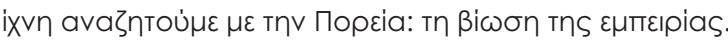

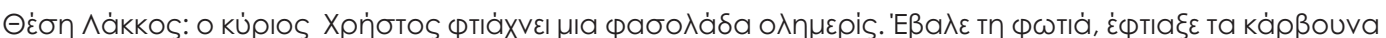

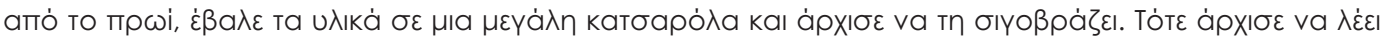

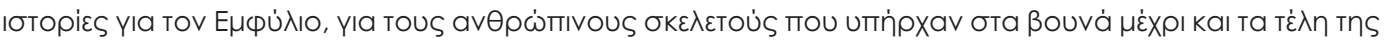

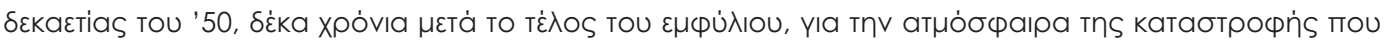
ṅтav akò

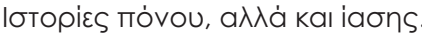

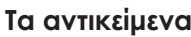

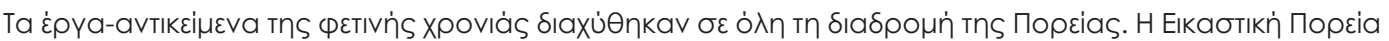

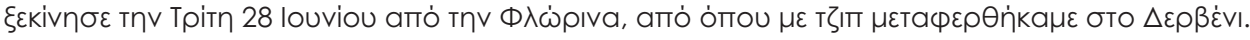

7. Richard Long , http://www.tate.org.uk/britain/exhibitions/richardlong/explore.shtm

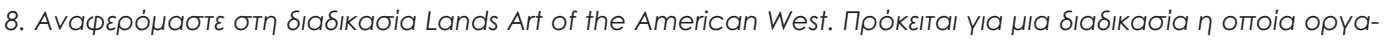

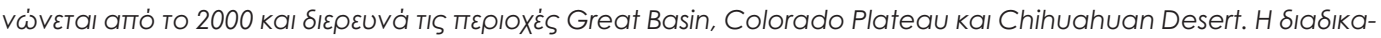

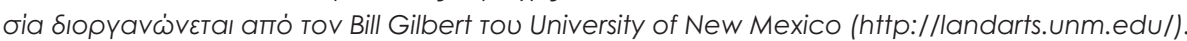

9. http://www.new-arts-frontiers.eu/images/final_report.pdf

10. http://www.visualsociology.org/conference.html 

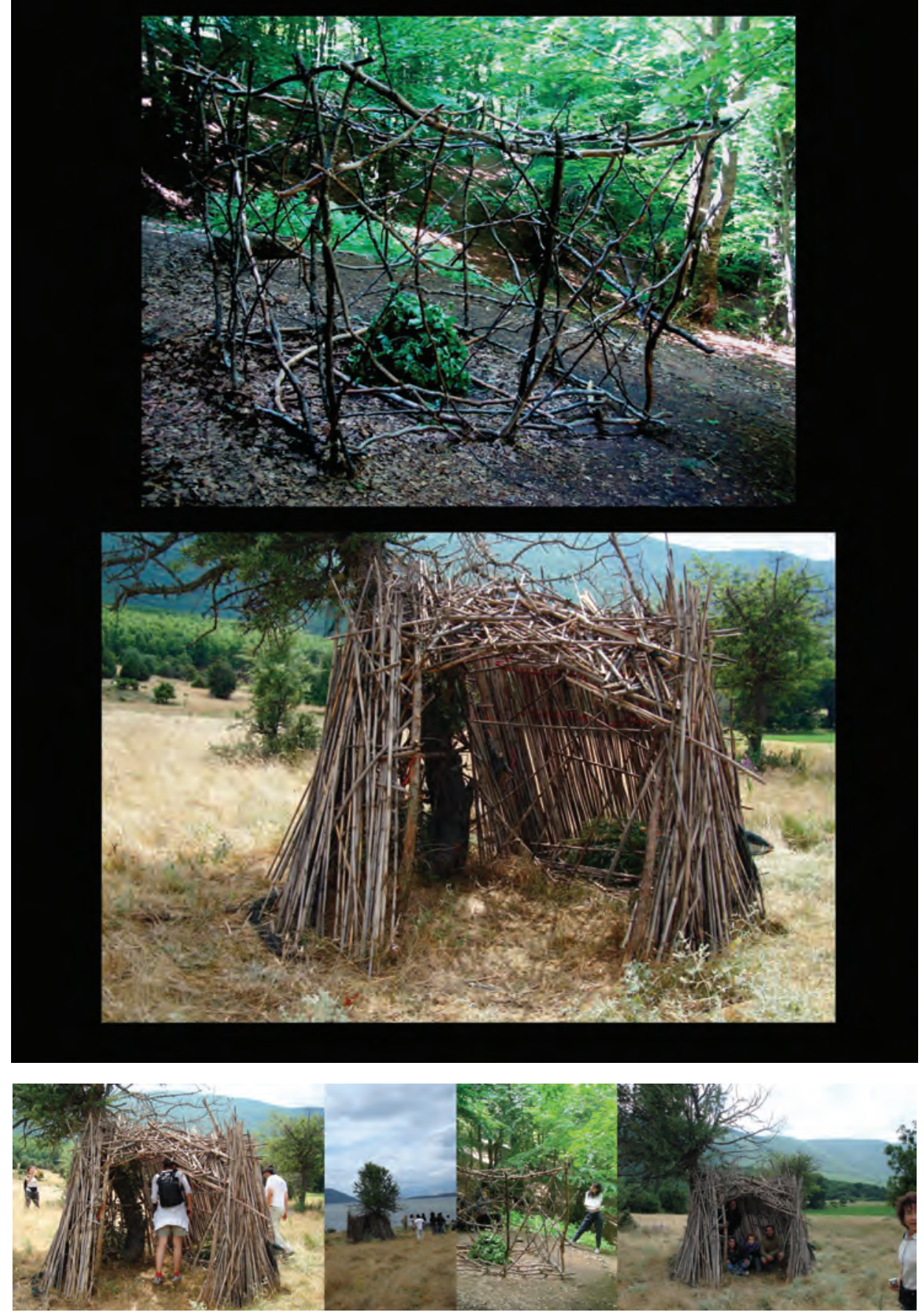

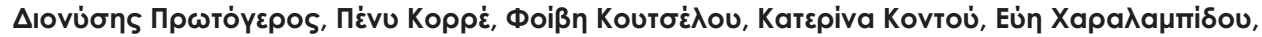

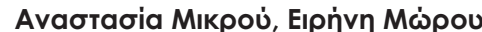

Kúßos

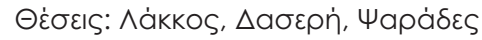

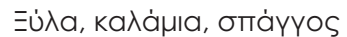

2011 


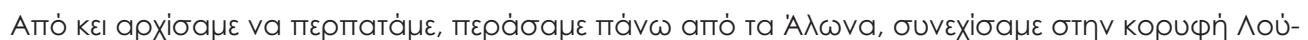

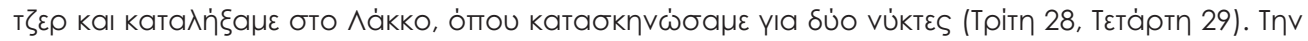

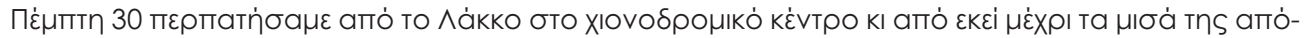

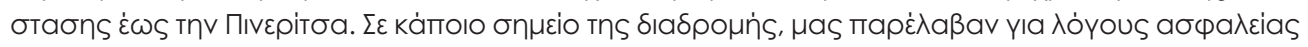

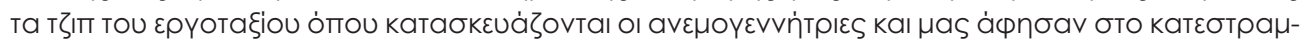

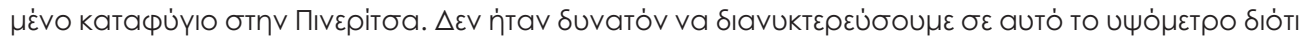

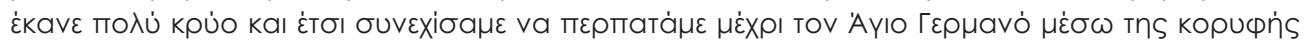

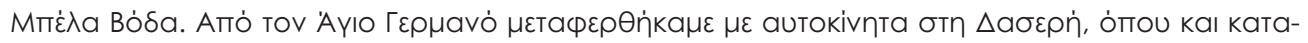

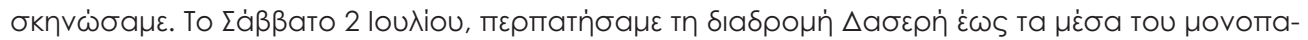

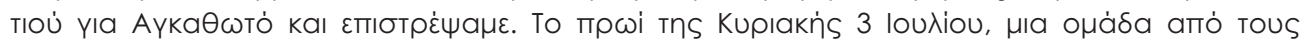

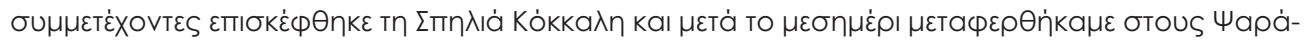

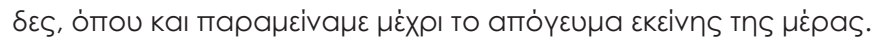

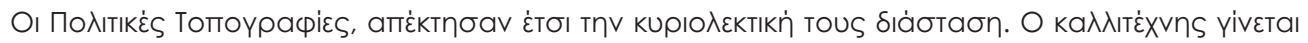

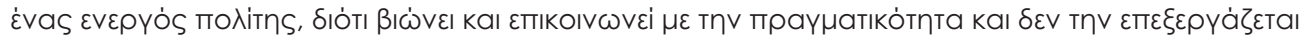

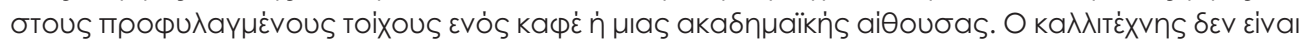

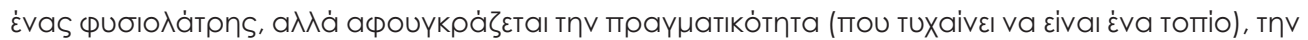

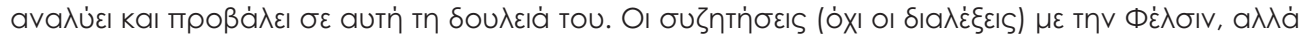

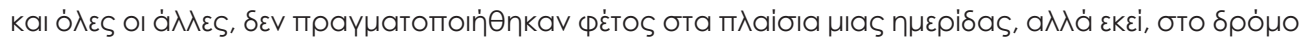

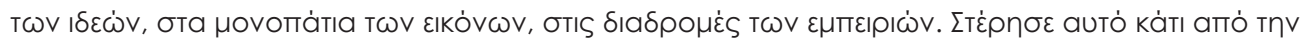

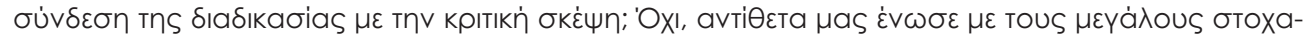

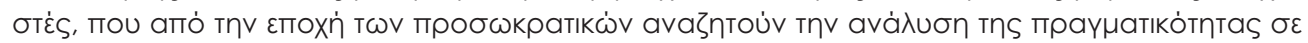

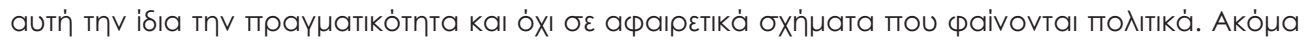

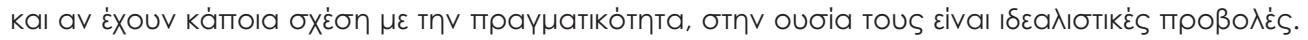

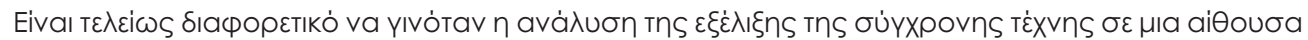

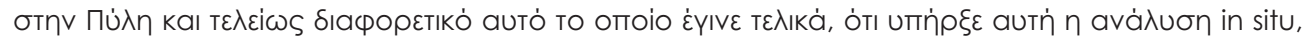

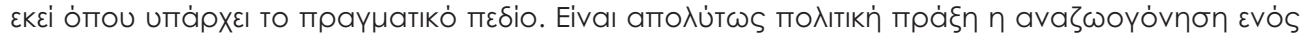

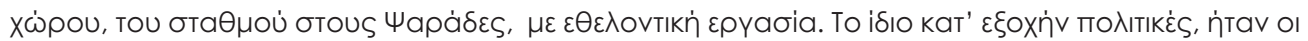

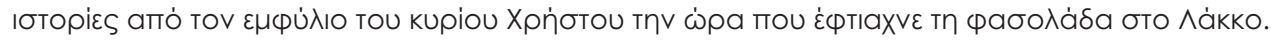

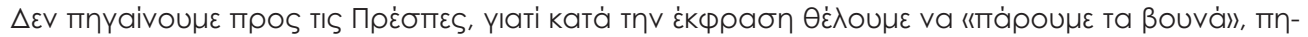

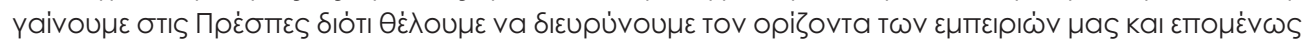

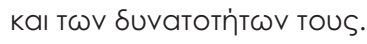

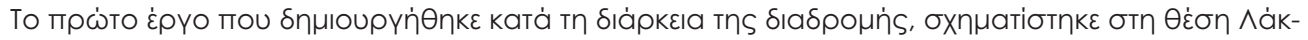

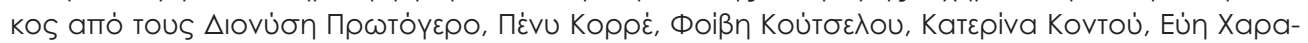

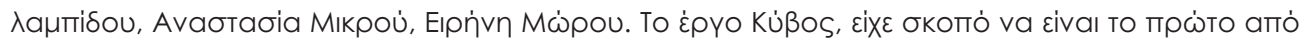

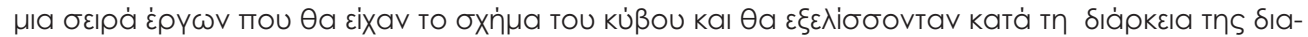

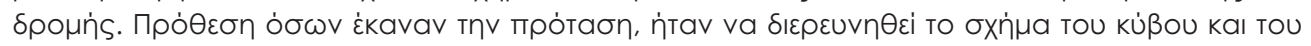

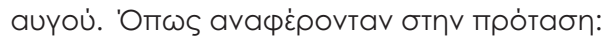

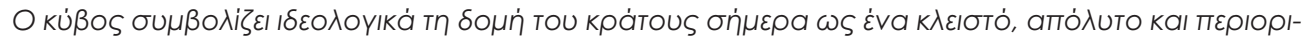

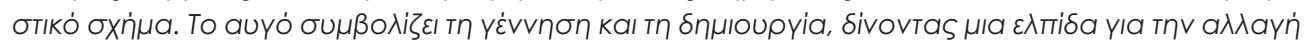

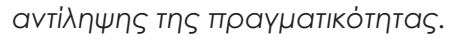

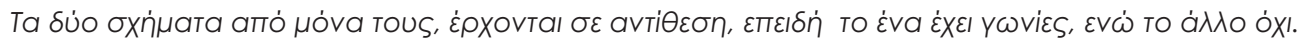

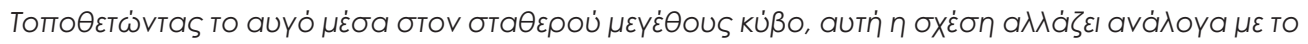
$\mu \dot{\varepsilon} Y \varepsilon \ominus \circ$ ऽ TOu auYoú.

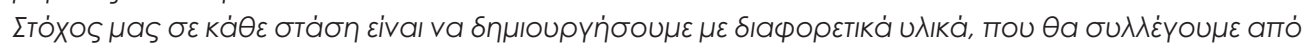

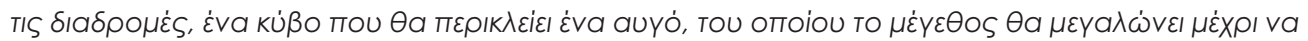

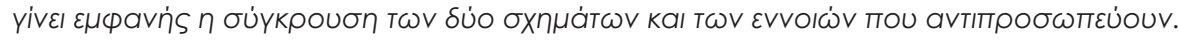




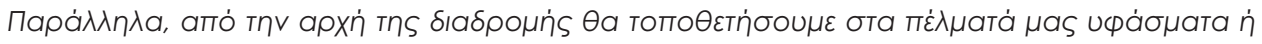

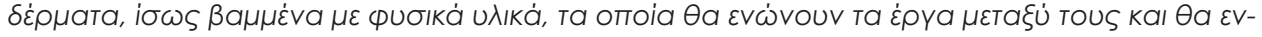

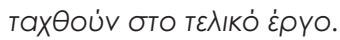

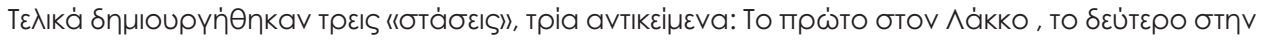

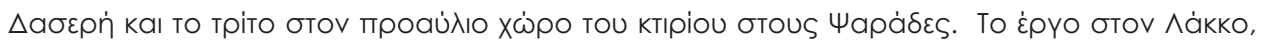

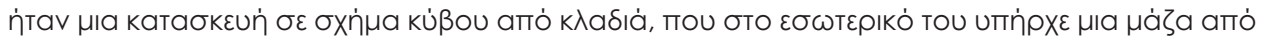

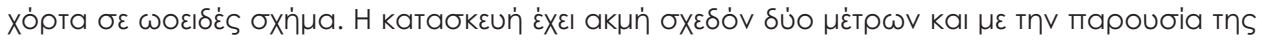

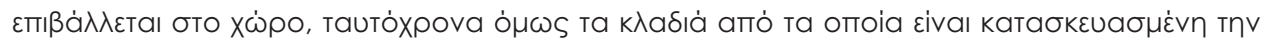

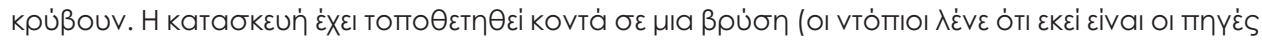

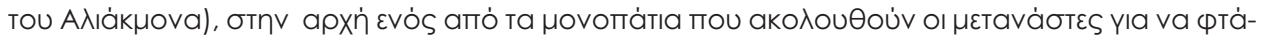

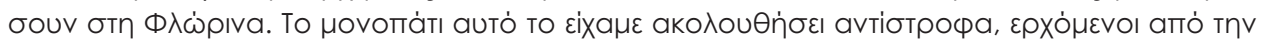

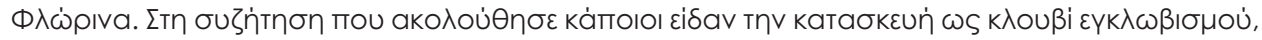

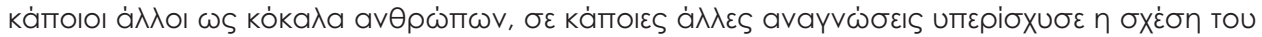

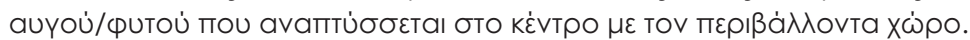

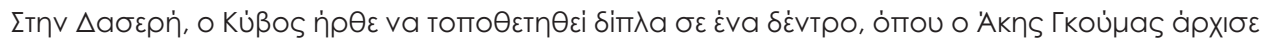

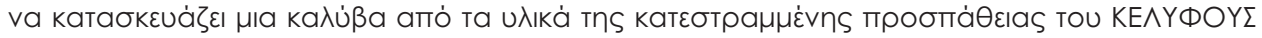

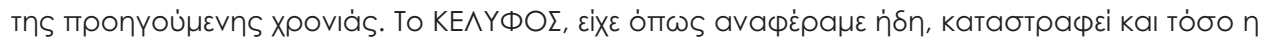

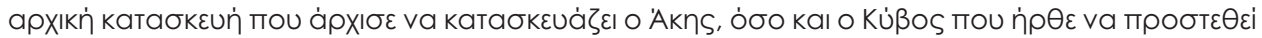

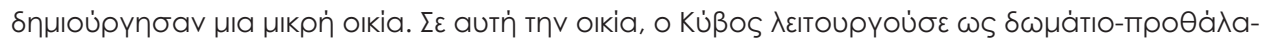

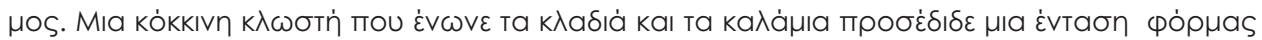

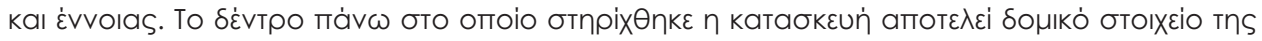

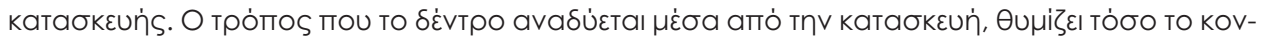

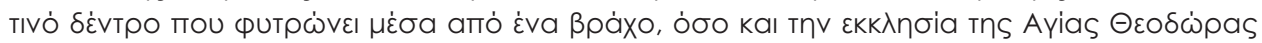

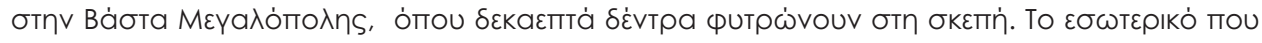

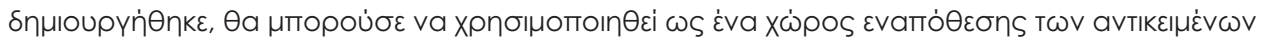

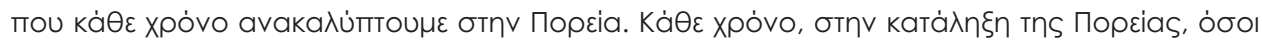

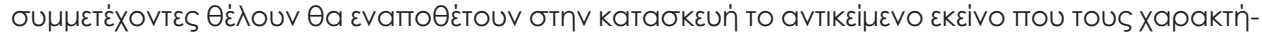

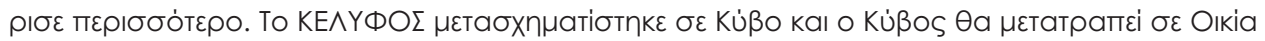

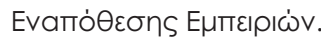

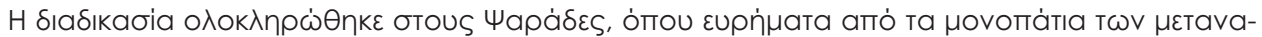

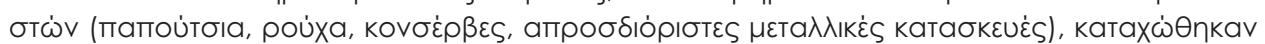

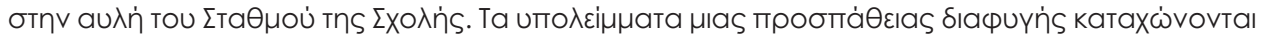

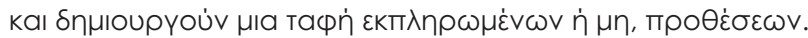

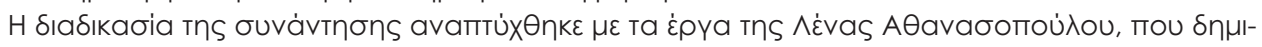

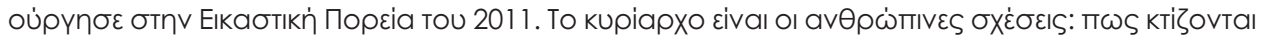

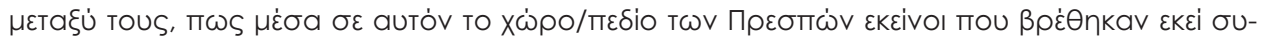

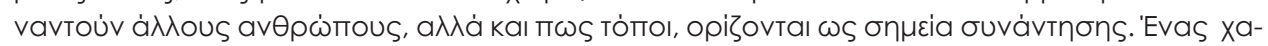

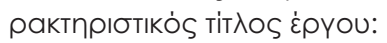

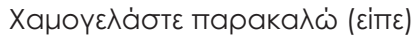

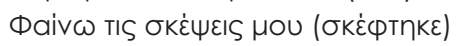

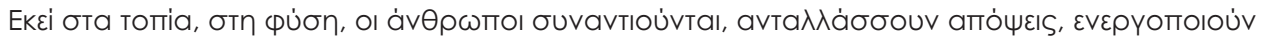

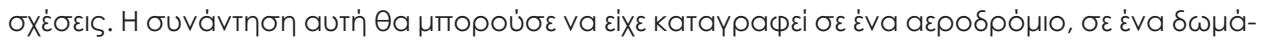

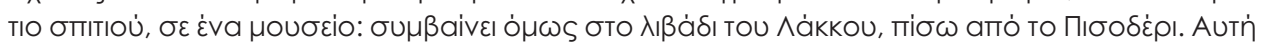

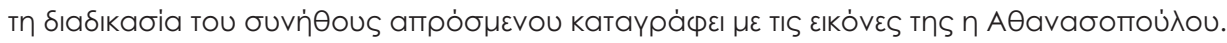




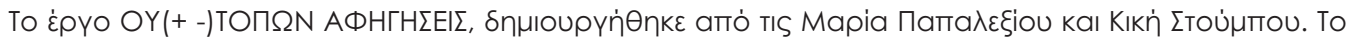

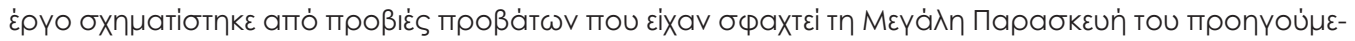

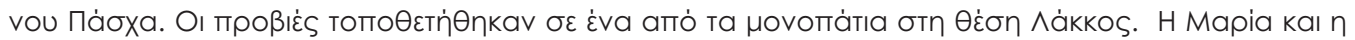

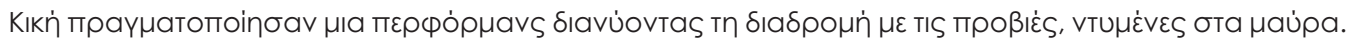

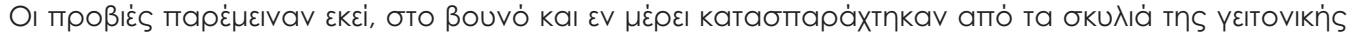

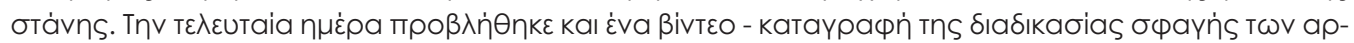

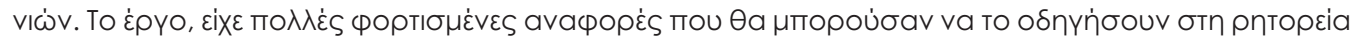

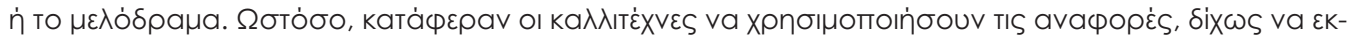

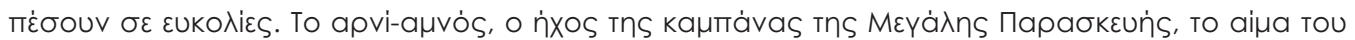

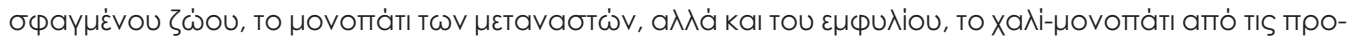

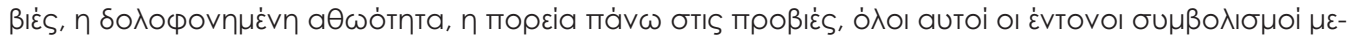

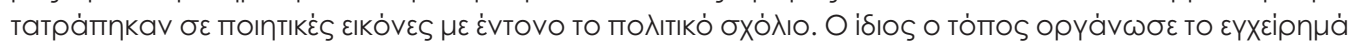

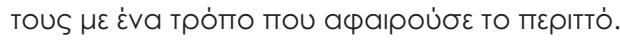

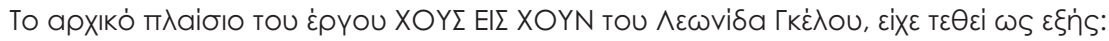

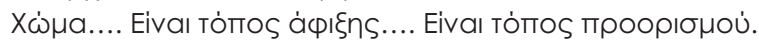

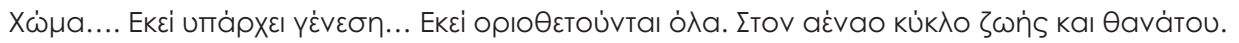

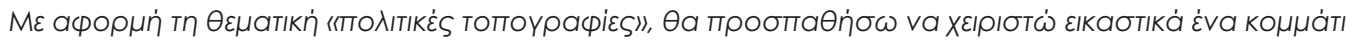

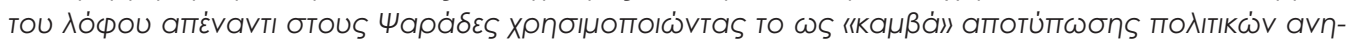

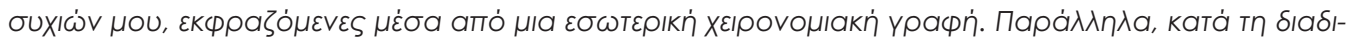

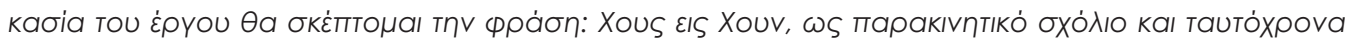

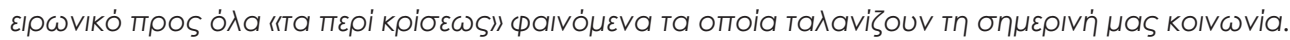

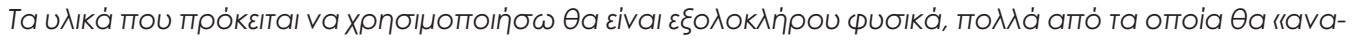

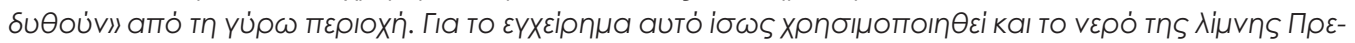
бாஸ்v.

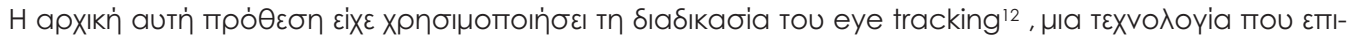

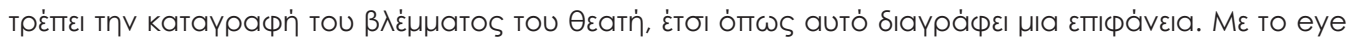

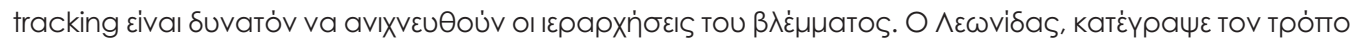

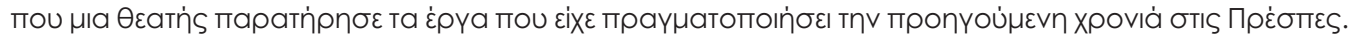

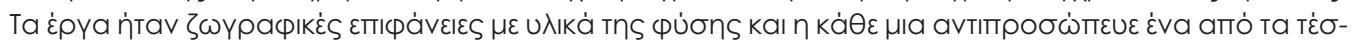

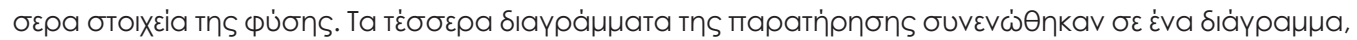

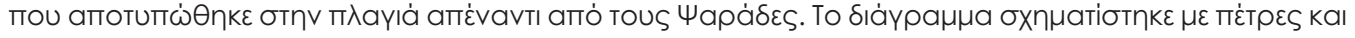

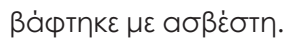

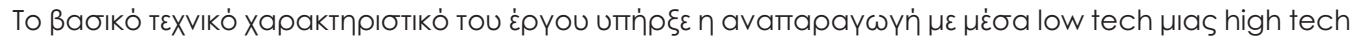

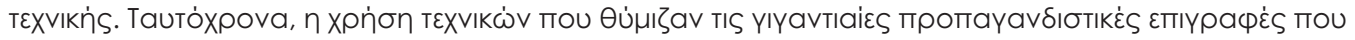

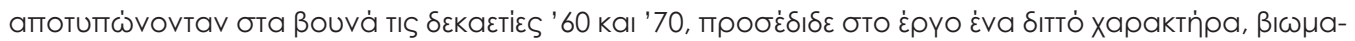

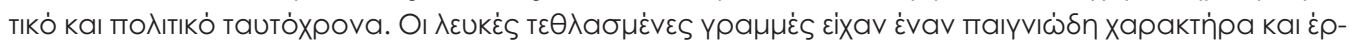

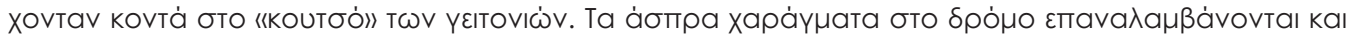

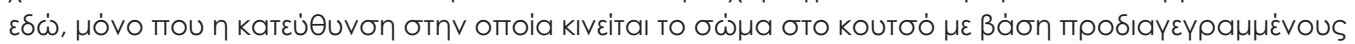

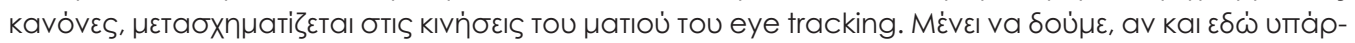

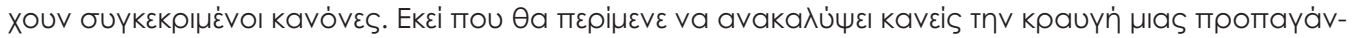

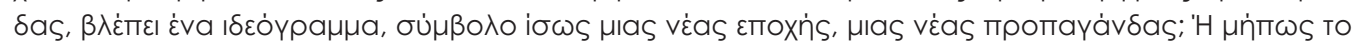

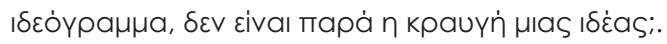

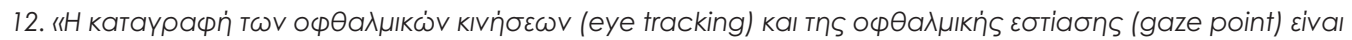

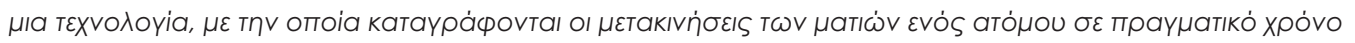

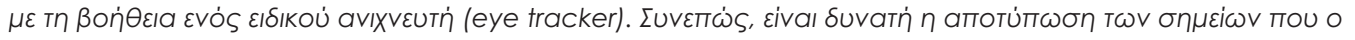

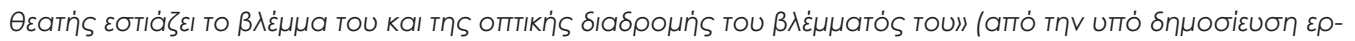

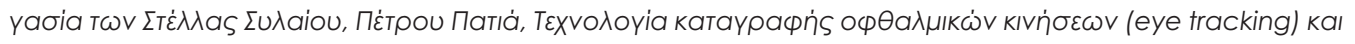

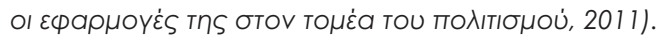



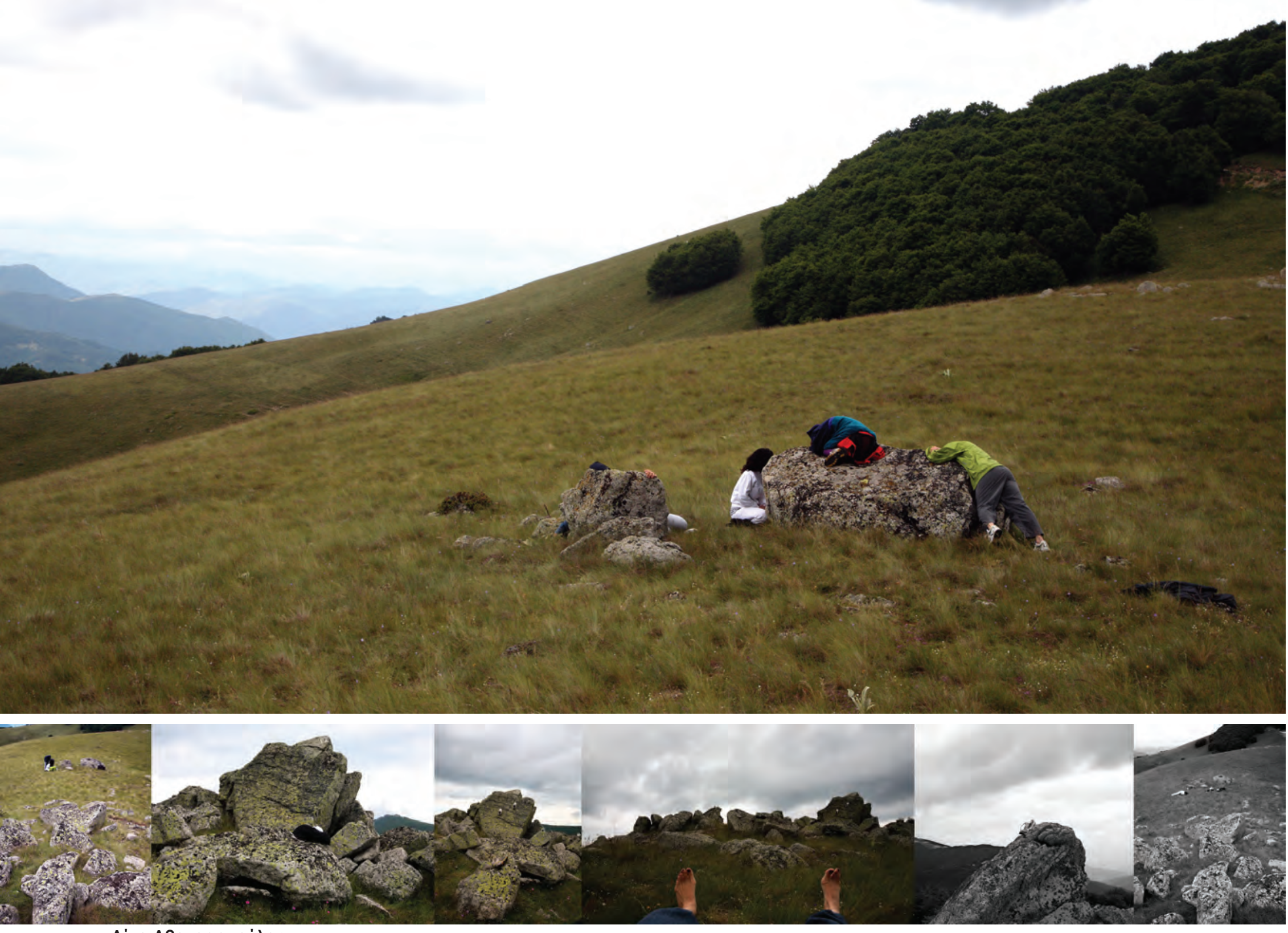

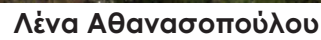

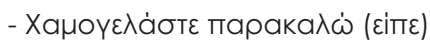

- Фaiv

^ákkos

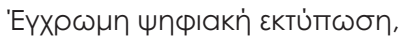

2011

96. 


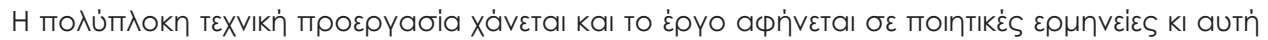

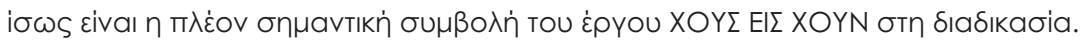

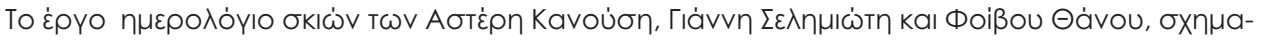

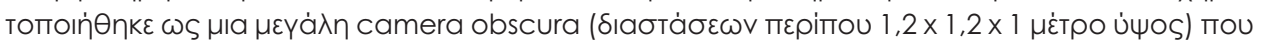

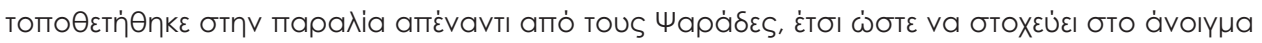

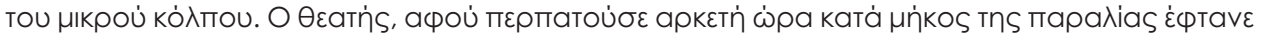

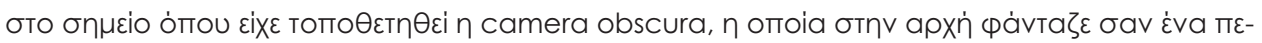

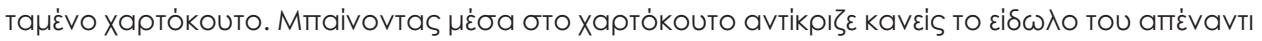

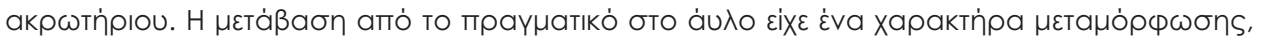

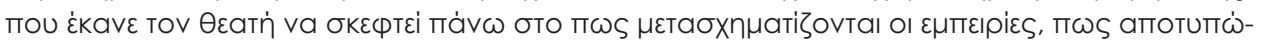

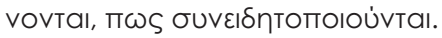

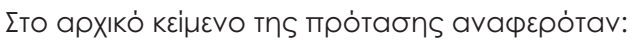

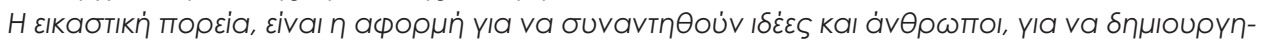

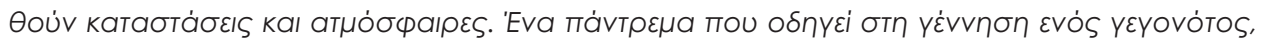

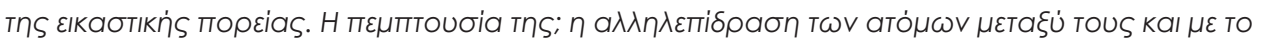

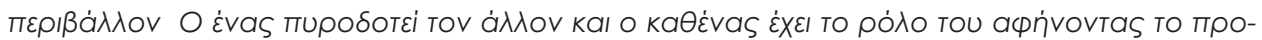

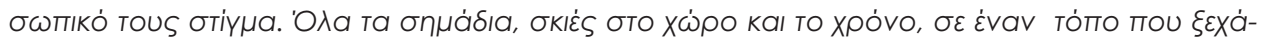

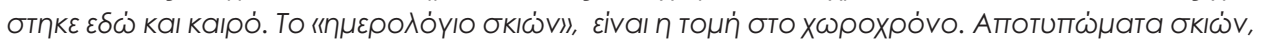

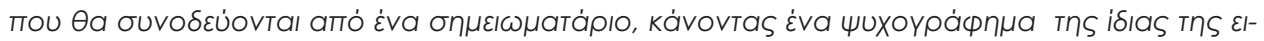

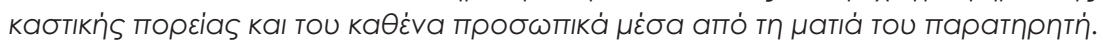

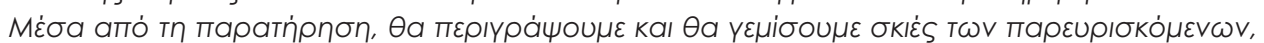

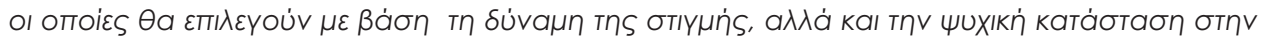

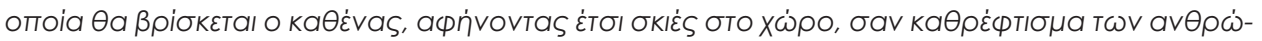

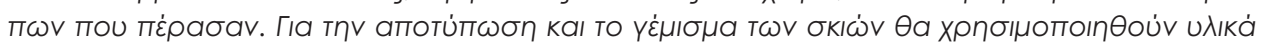

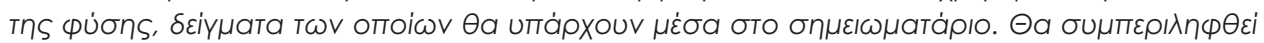

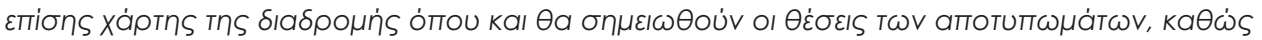

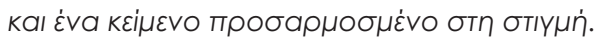

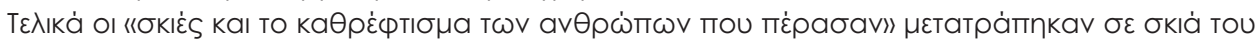

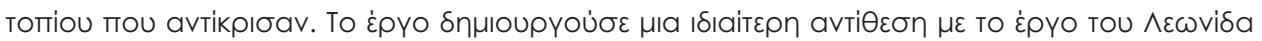

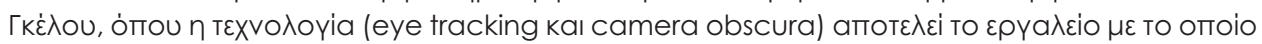

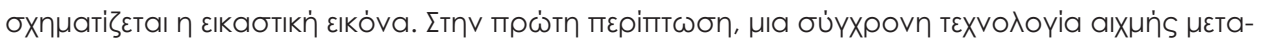

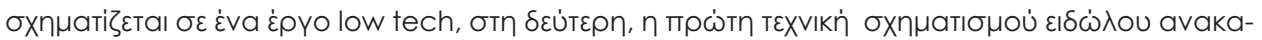

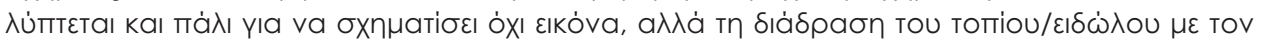

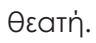

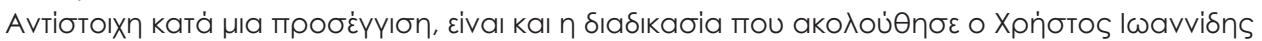

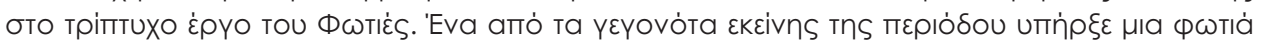

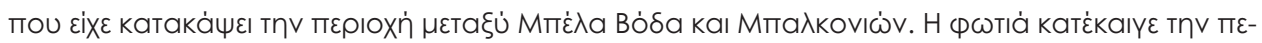

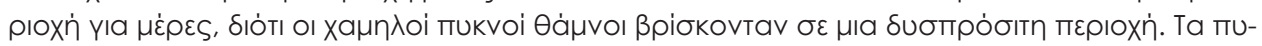

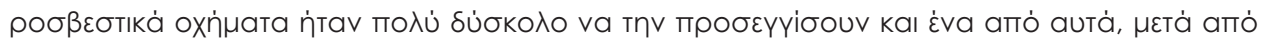

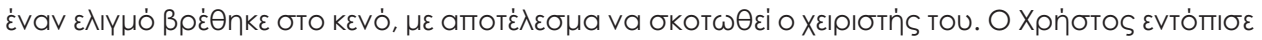

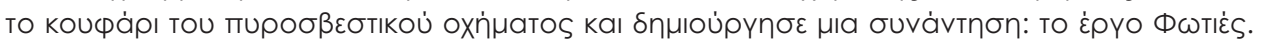

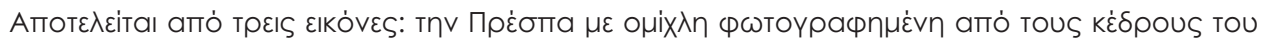

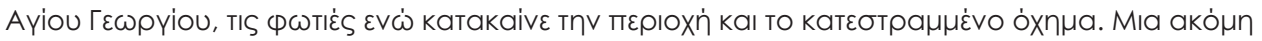

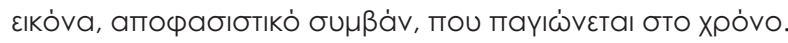




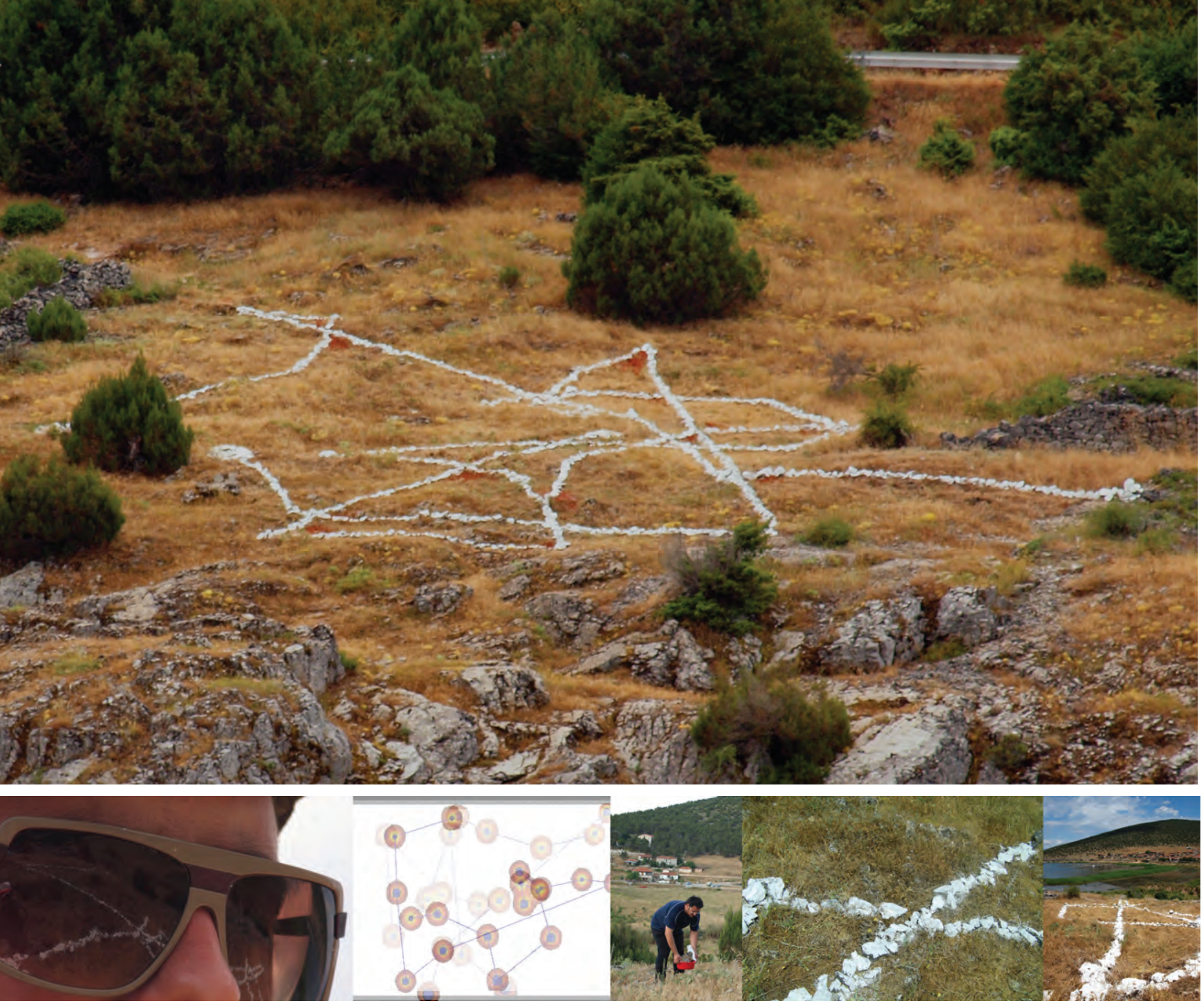

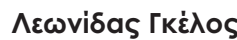

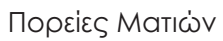

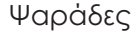

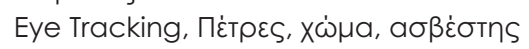

2011

98. 


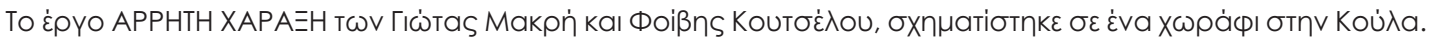

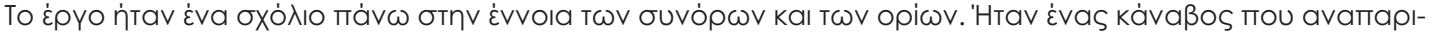

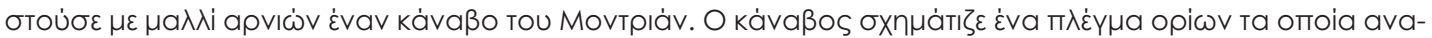

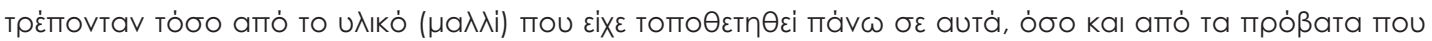

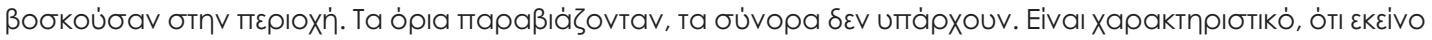

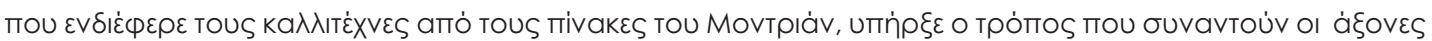

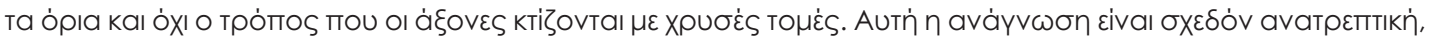

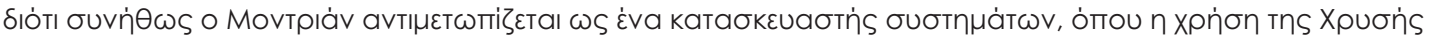

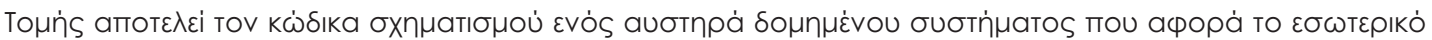

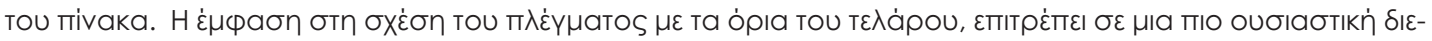

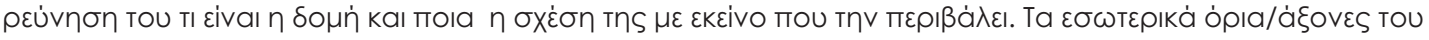

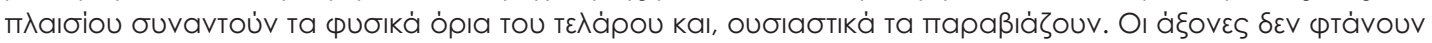

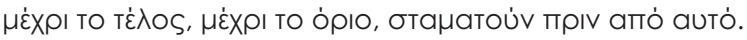

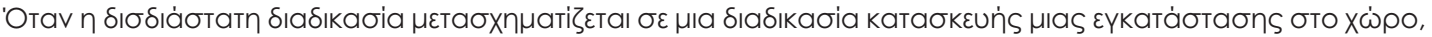

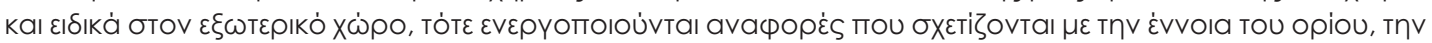

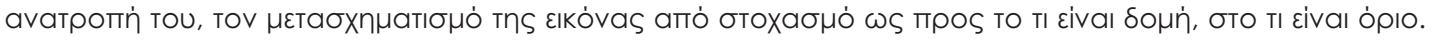

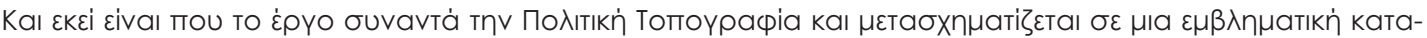

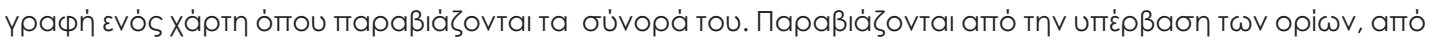

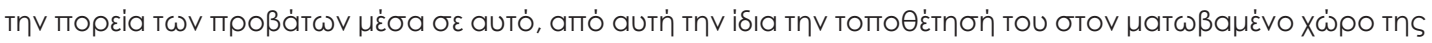

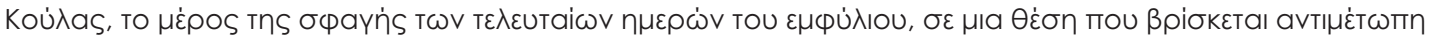

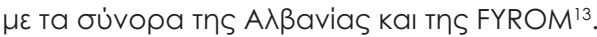

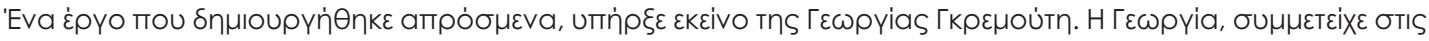

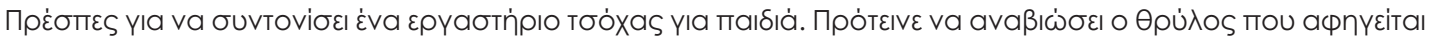

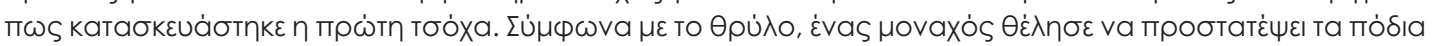

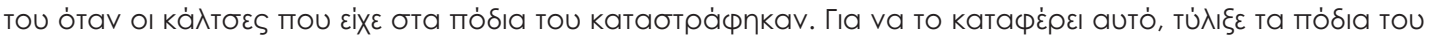

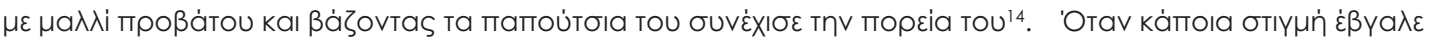

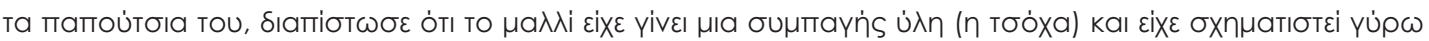

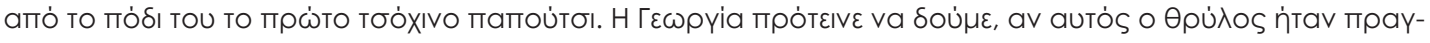

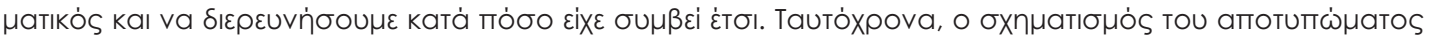

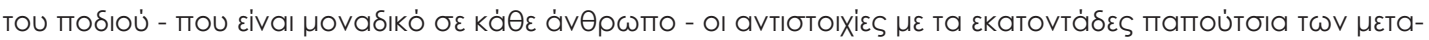

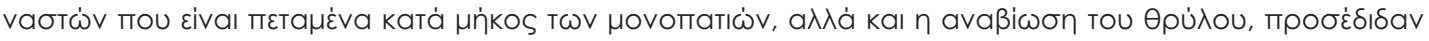

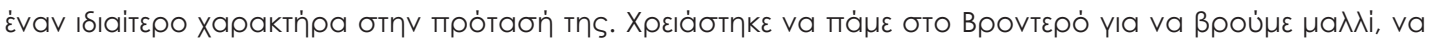

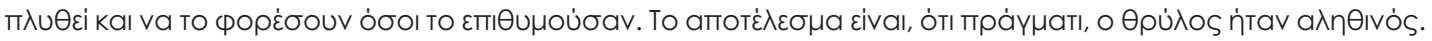

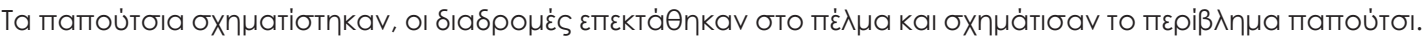

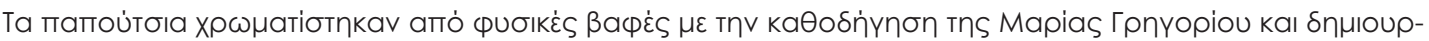

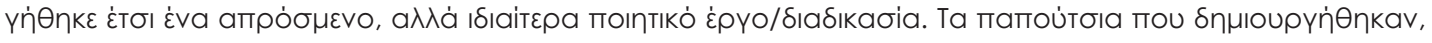

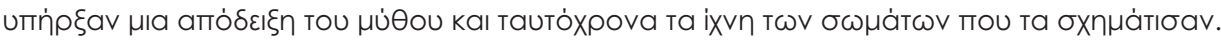

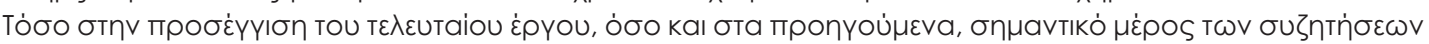

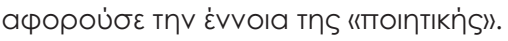

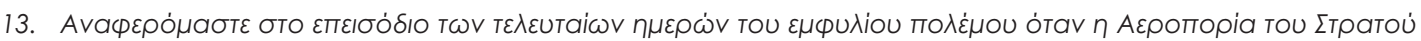

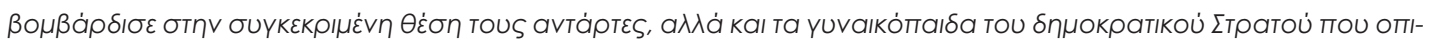

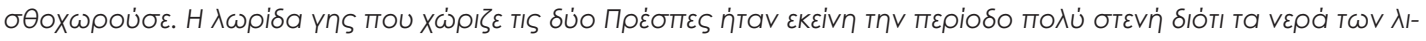

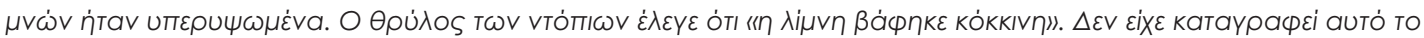

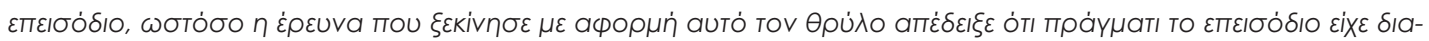

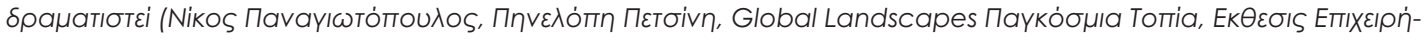

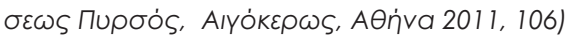

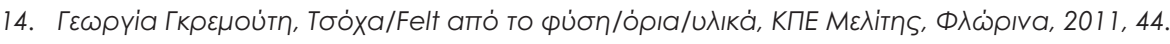




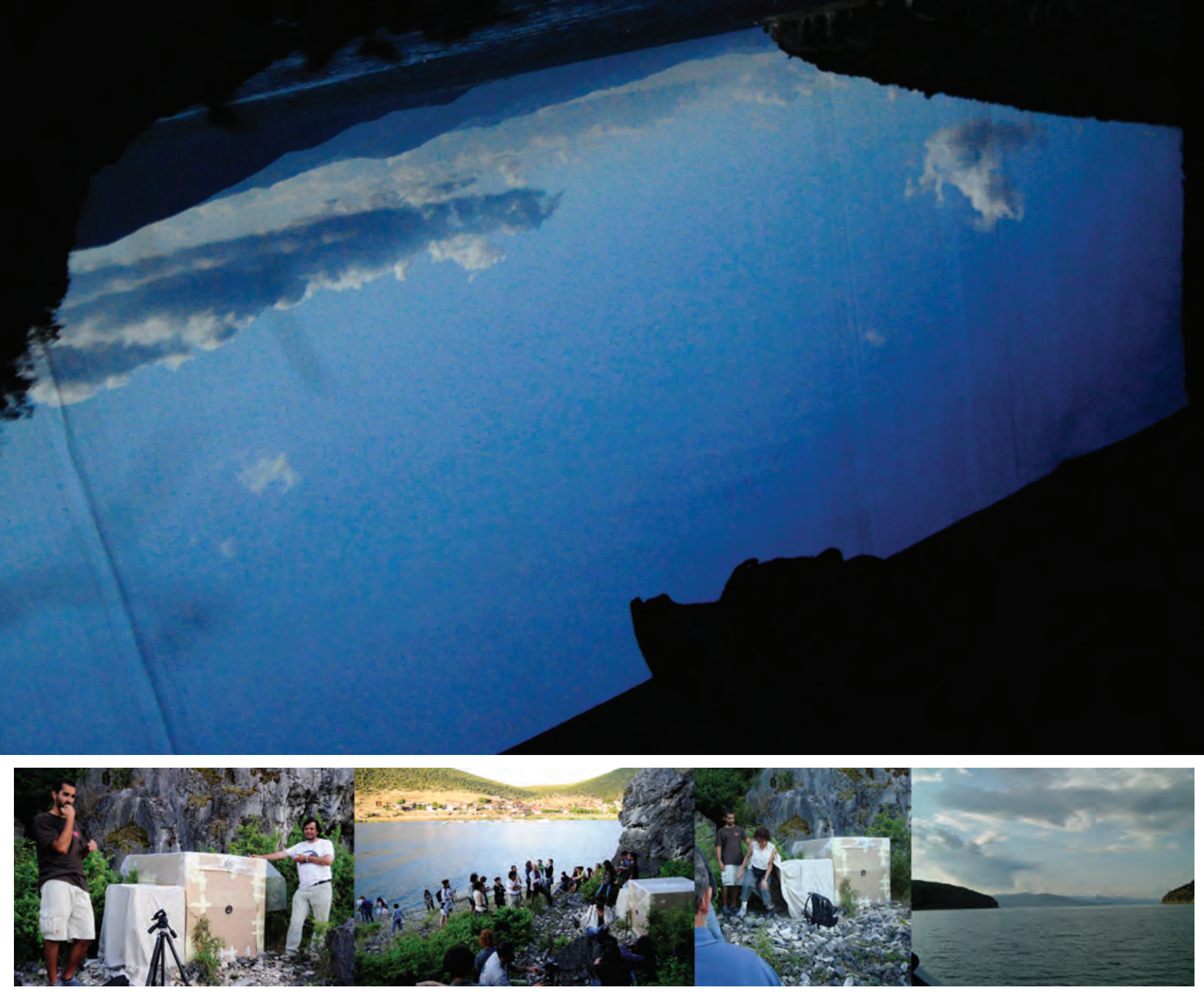

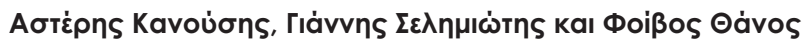

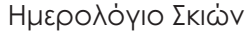

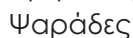

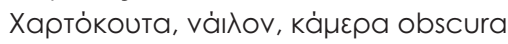

2011

100. 


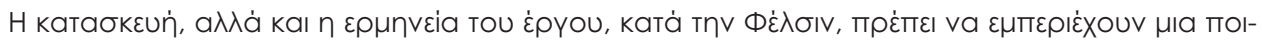

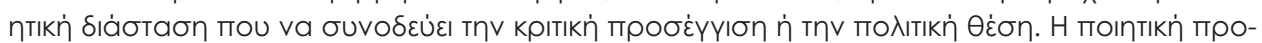

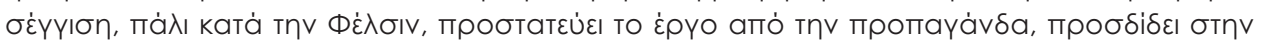

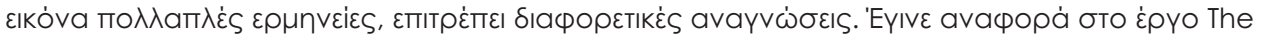

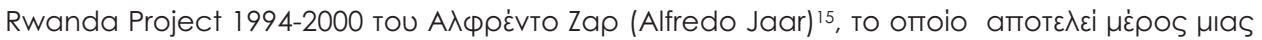

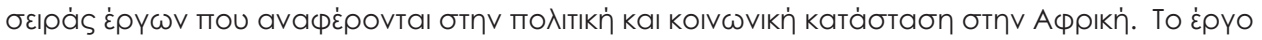

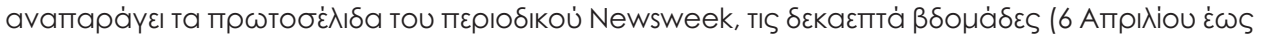

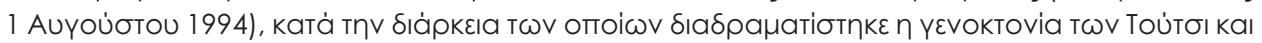

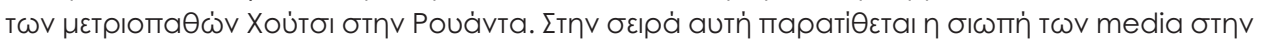

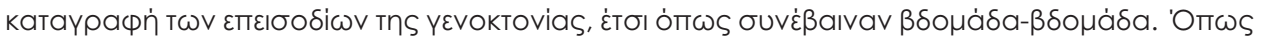

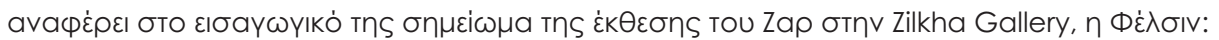

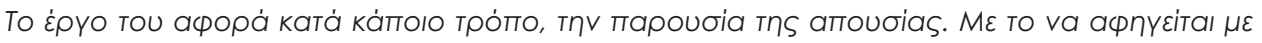

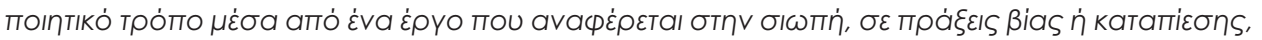

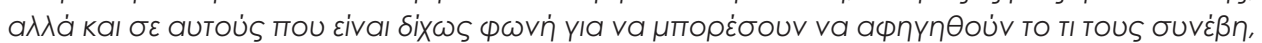

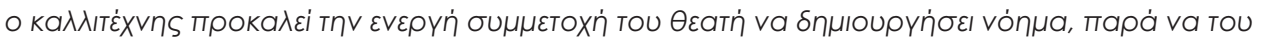
TO $\varepsilon \Pi \sqcap \beta \dot{\lambda} \lambda \lambda \varepsilon 1^{16}$.

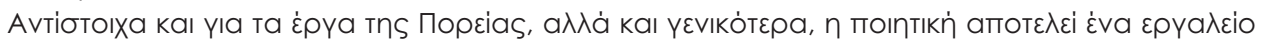
по

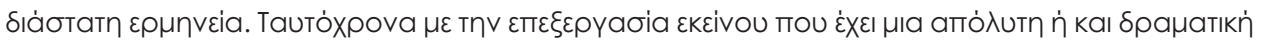

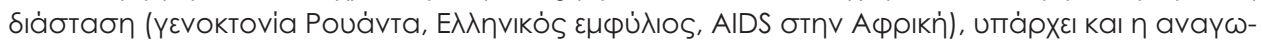

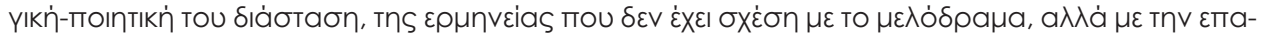

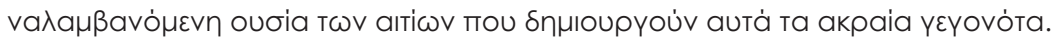

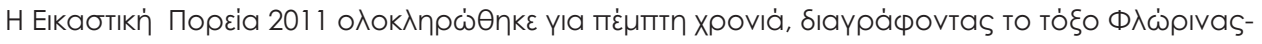

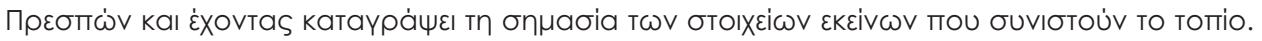

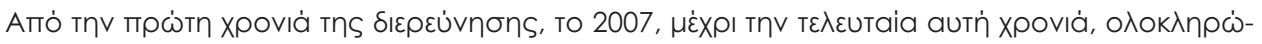

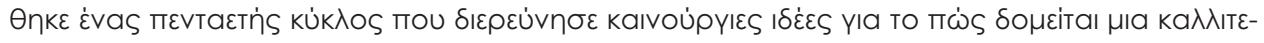

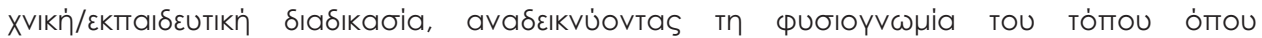

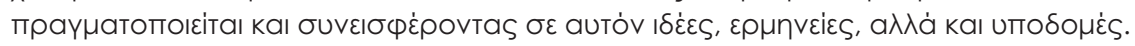

r.z.

15. http://www.alfredojaar.net/indexl.html

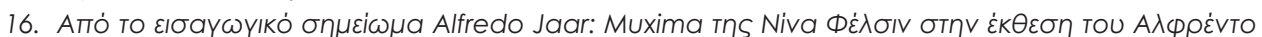
Zap oTn Zilkha Gallery (2007) 


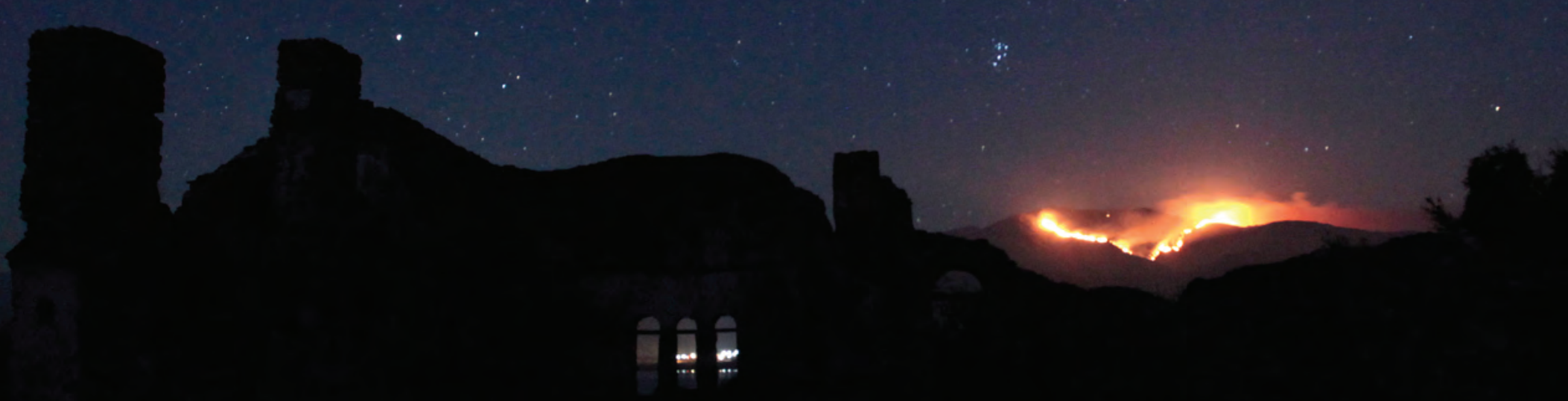

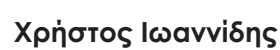

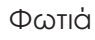

Прє்๐ாع

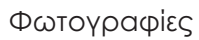

2011

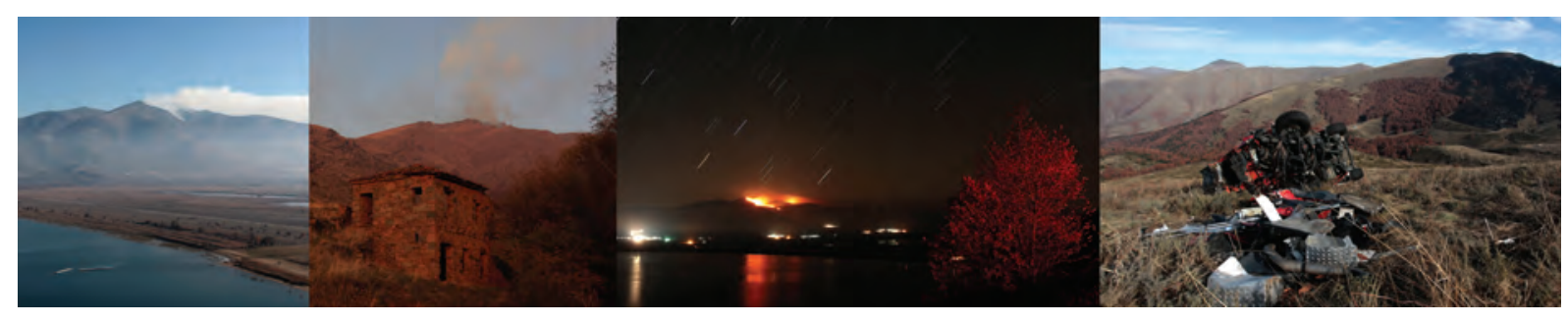

102. 


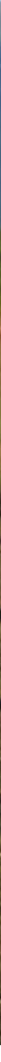

\section{Гіம்та Макриं,

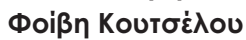 \\ Appntn Xápaşn

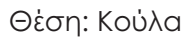

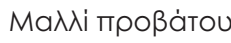 \\ 2011}

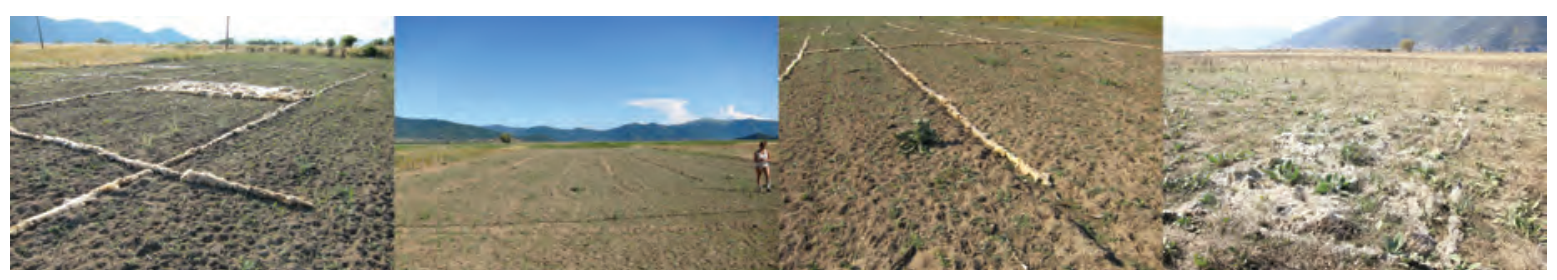




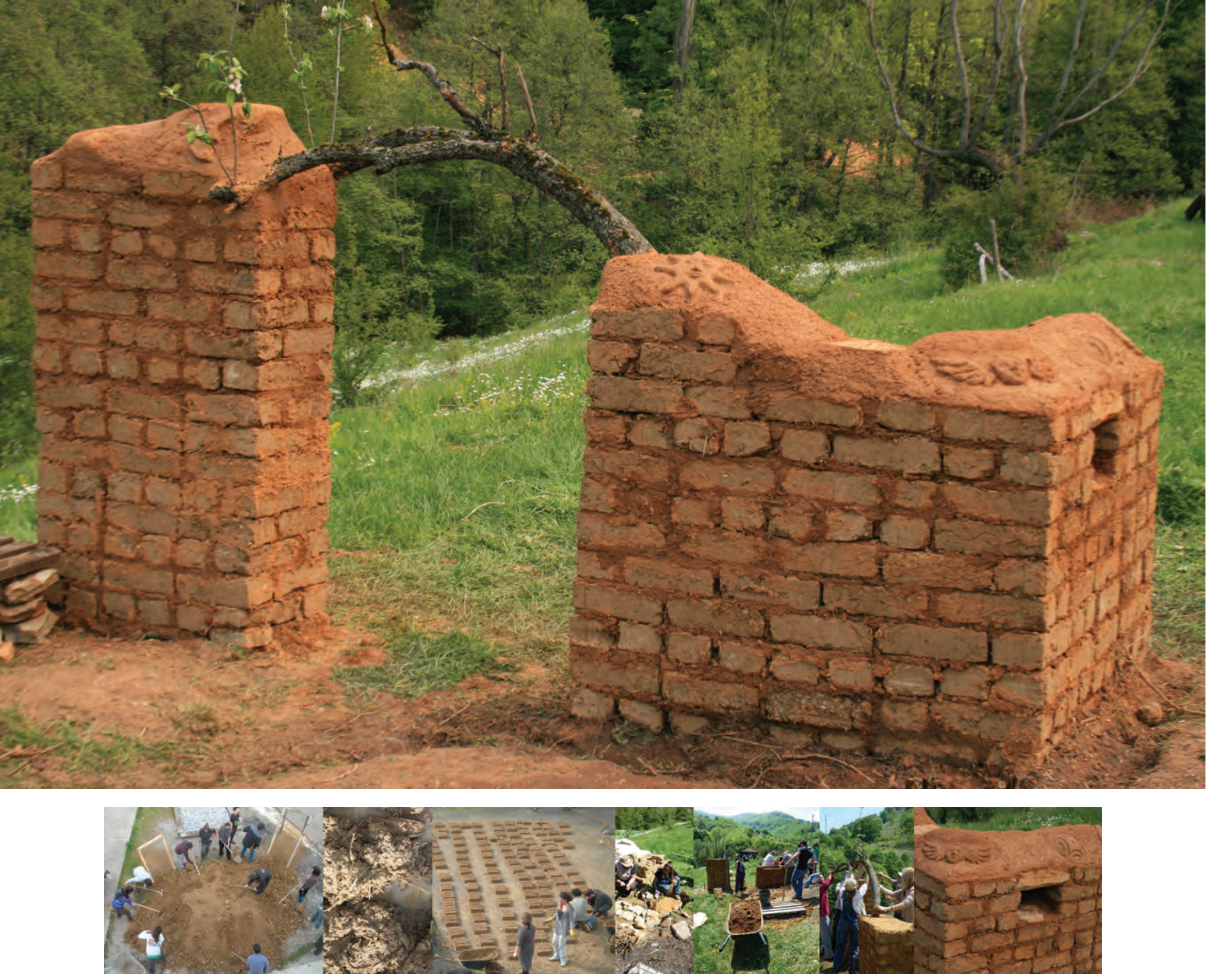

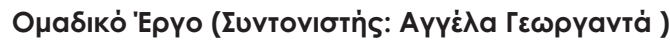

Порто́vı

$\Delta$ робоппуn்

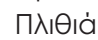

2011 


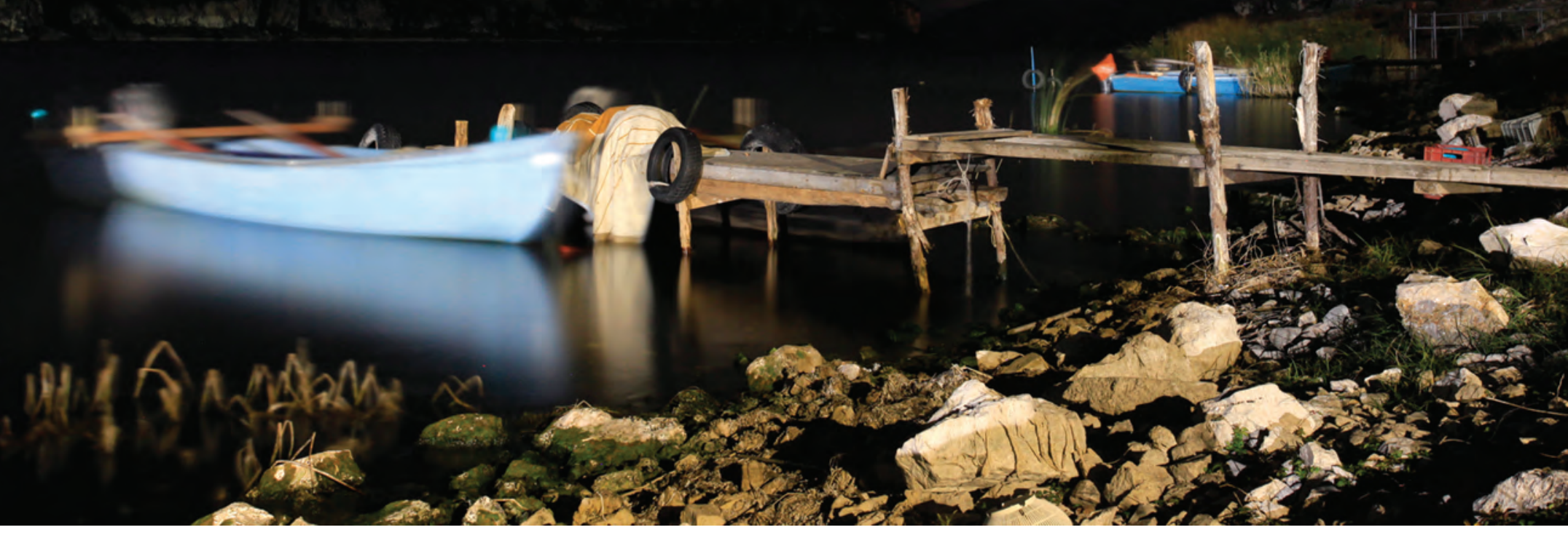

